\title{
Internal and external green-blue agricultural water footprints of nations, and related water and land savings through trade
}

\author{
M. Fader ${ }^{1,2}$, D. Gerten ${ }^{1}$, M. Thammer ${ }^{1}$, J. Heinke ${ }^{1}$, H. Lotze-Campen ${ }^{1}$, W. Lucht ${ }^{1,3}$, and W. Cramer ${ }^{1,4}$ \\ ${ }^{1}$ Potsdam Institute for Climate Impact Research, Telegraphenberg, 14473 Potsdam, Germany \\ ${ }^{2}$ International Max Planck Research School on Earth System Modelling, Bundesstr. 53, 20146 Hamburg, Germany \\ ${ }^{3}$ Department of Geography, Humboldt University of Berlin, Berlin, Germany \\ ${ }^{4}$ Institute of Earth and Environmental Sciences, Potsdam University, Potsdam, Germany
}

Received: 31 December 2010 - Published in Hydrol. Earth Syst. Sci. Discuss.: 18 January 2011

Revised: 20 April 2011 - Accepted: 21 May 2011 - Published: 27 May 2011

\begin{abstract}
The need to increase food production for a growing world population makes an assessment of global agricultural water productivities and virtual water flows important. Using the hydrology and agro-biosphere model LPJmL, we quantify at $0.5^{\circ}$ resolution the amount of blue and green water (irrigation and precipitation water) needed to produce one unit of crop yield, for 11 of the world's major crop types. Based on these, we also quantify the agricultural water footprints (WFP) of all countries, for the period 1998-2002, distinguishing internal and external WFP (virtual water imported from other countries) and their blue and green components, respectively. Moreover, we calculate water savings and losses, and for the first time also land savings and losses, through international trade with these products. The consistent separation of blue and green water flows and footprints shows that green water globally dominates both the internal and external WFP ( $84 \%$ of the global WFP and $94 \%$ of the external WFP rely on green water). While no country ranks among the top ten with respect to all water footprints calculated here, Pakistan and Iran demonstrate high absolute and per capita blue WFP, and the US and India demonstrate high absolute green and blue WFPs. The external WFPs are relatively small (6\% of the total global blue WFP, $16 \%$ of the total global green WFP). Nevertheless, current trade of the products considered here saves significant water volumes and land areas $\left(\sim 263 \mathrm{~km}^{3}\right.$ and $\sim 41 \mathrm{Mha}$, respectively, equivalent to $5 \%$ of the sowing area of the considered crops and $3.5 \%$ of the annual precipitation on this area). Relating the proportions of external to internal blue/green WFP to the per capita WFPs allows recognizing that only a few countries consume more water from abroad than from their own territory and
\end{abstract}

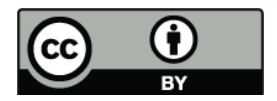

Correspondence to: $\mathrm{M}$. Fader (mfader@ pik-potsdam.de) have at the same time above-average WFPs. Thus, countries with high per capita water consumption affect mainly the water availability in their own country. Finally, this study finds that flows/savings of both virtual water and virtual land need to be analysed together, since they are intrinsically related.

\section{Introduction}

About $70 \%$ of current water withdrawals are for agricultural production (Molden et al., 2007), and it is expected that population growth, economic development, urbanization, dietary changes and climate change will further increase water demand for food production in the future (Rosegrant and Sombilla, 1997; Vörösmarty et al., 2000; Steinfeld et al., 2006; Liu and Savenije, 2008; Liu et al., 2008). The global consumption of "blue" water (taken from rivers, reservoirs, lakes and aquifers and used for irrigation) presently amounts to $927-1660 \mathrm{~km}^{3} \mathrm{yr}^{-1}$ according to recent estimates (Rost et al., 2008; Hoff et al., 2010). However, about 3000 to $6000 \mathrm{~km}^{3} \mathrm{yr}^{-1}$ of "green" water (precipitation stored in the soil and evapotranspired on cropland) are consumed in addition to sustain rainfed agriculture and parts of irrigated agriculture (Rost et al., 2008; Liu et al., 2009; Hoff et al., 2010). These numbers highlight the outstanding contribution of green water to crop production and, thus, the need to consider this resource in water availability and water scarcity studies (Rockström et al., 2009).

Regional differences in the amount of water needed to produce a unit of crop biomass or yield (i.e. the virtual water content, VWC) can benefit the mitigation of regional water scarcity. Water-scarce countries often import waterintensive agricultural products from water-abundant countries, or from countries where VWC is lower due to more

Published by Copernicus Publications on behalf of the European Geosciences Union. 
beneficial climate (and management) conditions (e.g. Oki and Kanae, 2004; Hoekstra and Chapagain, 2007; Yang and Zehnder, 2007). Thus, together with the traded commodities, countries trade the water that was needed for their production (though in virtual form, since it is not physically present in the product). This is called virtual water flow (VWF) or virtual water trade. It is important to differentiate between green and blue virtual water contents and flows in agriculture, because blue water can be redirected more easily to other purposes. This is why blue water has higher opportunity costs (Hoekstra, 2010) and its use has environmental impacts other than green water use (see e.g. Pfister et al., 2009 , for consequences of blue water consumption for cotton production).

The water footprint (WFP), developed by Hoekstra and Hung (2002), is a measure of the water intensity and origin of the products consumed by a country, a person or a company, considering both own production (internal WFP, mostly derived for a country) and imports from other countries (external WFP - see Glossary of terms used herein at the end of the text). In the study by Hoekstra and Chapagain (2007), the global water footprint for a wide range of agricultural, livestock and industrial goods was estimated to be $7450 \mathrm{~km}^{3} \mathrm{yr}^{-1}$ in absolute terms and $1240 \mathrm{~m}^{3} \mathrm{yr}^{-1}$ on a per capita basis, however with pronounced differences among countries. For example, North America and Western Europe appear to have much higher per capita WFPs than China and most South African countries. The global external WFP was reported to account for $16 \%$ of the total WFP (Hoekstra and Chapagain, 2007).

Some recent global (modelling) studies explicitly accounted for the contributions of green and blue water to international VWFs and WFPs, though with several shortcomings. For example, the studies by Chapagain et al. (2005), Yang et al. (2006) and Aldaya et al. (2010) were restricted to a narrow selection of commodities or crops, they were not able to account explicitly for the dynamic interactions between soil moisture and plants, and they were based on VWC calculated at country or state level while neglecting country-internal differences. Some of these shortcomings were overcome by the study of Hanasaki et al. (2010) which, however, did not consider the coexistence of different crop types in a grid cell and focused on virtual water exports only. The grid-based study by Mekonnen and Hoekstra (2010a) was restricted to wheat and did not consider plant physiologic water stress under irrigated conditions (i.e. when due to plant hydraulic traits, soil water supply remains below atmospheric demand even if the soil is saturated; Gerten et al. 2004, 2007). A new journal article by Mekonnen and Hoekstra (2010b), which is still under review, quantified WFPs based on grid cell VWCs for a large list of commodities using the same method. Liu et al. (2009) and Liu and Yang (2010) used a crop model with systematic calculations for growing periods (choosing the one with the maximal yield output, which does not reflect the reality every- where). Furthermore, to our best knowledge, the intimate connection between green water use and land resources was not addressed quantitatively in any WFP study, which would be a step forward in the analysis and quantification of tradeoffs for agricultural water use, as pointed out by Yang and Zehnder (2007).

The present global-scale study advances the field by specifically quantifying both the green and the blue internal and external WFPs of countries for a majority of the world's crop types, based on a process-detailed and highresolution $\left(0.5^{\circ}\right)$ representation of the underlying VWC as computed by the LPJmL dynamic global vegetation and water balance model (Bondeau et al., 2007; Rost et al., 2008). Additionally, this is the first study quantifying virtual land savings associated with virtual land flows.

\section{General modelling approach and data}

\subsection{General characteristics of the LPJmL model}

LPJmL is a process-based, ecohydrological biosphere and agrosphere model that simulates carbon and water stocks and fluxes in direct coupling with vegetation dynamics. It considers nine plant functional types that represent the variety of woody and herbaceous vegetation types at biome level (Sitch et al., 2003); pasture (managed grassland); and eleven crop functional types (CFTs) that represent a number of the world's major crop types (temperate cereals, maize, rice, tropical cereals, temperate roots, tropical roots, rapeseed, groundnuts, soybeans, pulses, sunflower; for details see Bondeau et al., 2007; Waha et al., 2011).

The CFTs considered in the model version used here cover approximately $53 \%$ of the world's cropping area. (Note that the remaining crops are also included, but since they are collectively and preliminarily parameterized as LPJmL continues to be developed, they are omitted from this analysis - only for reasons of comparison with other studies we present some global results including these crops as well). Each CFT represents irrigated and rainfed areas according to a modification of the MIRCA2000 land use dataset (Portmann et al., 2010, see Fader et al., 2010). Numerous studies have evaluated and validated LPJmL and its predecessor LPJ, most recently Bondeau et al. (2007) for crop yields and phenology, Fader et al. (2010) for yields and VWC, Gerten et al. (2004) and Biemans et al. (2009) for river discharge, Rost et al. (2008) for irrigation water requirements and Waha et al. (2011) for sowing dates.

\subsection{Model setup and data}

In order to bring the distribution of natural vegetation and the soil carbon pools in equilibrium, we carried out a spin-up simulation, for which the climate of the period 1901-1930 was repeated 30 times. Subsequently, we performed a transient model run for the study period 1998-2002, forced by 
monthly air temperature, precipitation and cloudiness (from the CRU TS3.0 database; http://badc.nerc.ac.uk/data/cru; last access: 10 December 2009), soil texture based on the FAO soil data set (as in Gerten et al., 2004), $\mathrm{CO}_{2}$ concentration, and land use patterns as described above. As an improvement to the former model versions which considered two soil layers, this model version includes five soil layers with root distributions adapted from Jackson et al. (1996) (Sibyll Schaphoff, unpublished data). This development had little influence on the results of the present study as compared to the previous version documented in Fader et al. (2010), since VWC mainly depends on yields and since yields are calculated with calibrated management intensities (see Sect. 3.1). LPJmL is run here at a spatial resolution of 30 arc-minutes globally and at a daily time step, with monthly climate data being interpolated to quasi-daily values as in Gerten et al. (2004).

Annual imports and exports of agricultural commodities were taken from the United Nation's COMTRADE database ("Commodity Trade Statistics Database", http:// comtrade.un.org; last access: 7 July 2009) and averaged for the period 1998-2002. For the purpose of this study some commodities had to be reclassified so that they correspond to the CFTs: wheat, rye and barley were aggregated to the class of temperate cereals, sorghum and millet to tropical cereals, dry and fresh peas and beans to pulses, and sugar beets to temperate roots. Only raw commodity classes were used.

Population data for the year 2000 were taken from Grübler et al. (2007) (http://www.iiasa.ac.at/Research/GGI/ DB), based on which per capita WFPs were calculated.

\section{Computations of water flows}

\subsection{Green and blue virtual water content}

LPJmL simulates water fluxes as described by Gerten et al. (2004) and Rost et al. (2008). Crop production and yields are simulated as described by Bondeau et al. (2007) and Fader et al. (2010) based on biophysical (including hydrological) conditions and management intensity, separately for irrigated and rainfed agriculture. In brief, CFT-specific sowing and harvesting dates are represented as a function of climate, allowing for simulation of shifts of the growing period in response to climatic variation and change. The sowing dates are calculated based on temperature and precipitation (Waha et al., 2011), photosynthesis is calculated following the Farquhar model (Sitch et al., 2003), and crop phenology and harvest dates are calculated based on the heat unit theory (see Bondeau et al., 2007 for details). LPJmL accounts for different, calibrated management intensities through three coupled parameters: the harvest index, the maximal achievable LAI and a parameter representing the heterogeneity of the fields (see Fader et al., 2010). It also accounts for the reduction of biomass and yields through water stress.
Irrigation is modelled to occur if soil moisture falls below $90 \%$ of the water holding capacity. This is also the case in flooded paddy rice areas that are classified as irrigation areas in the land use dataset. It is assumed that the CFTs' gross irrigation water requirements - computed from the ratio between atmospheric transpirational demand and soil moisture supply while considering country-scale irrigation efficiencies - can always be fulfilled (details in Rost et al., 2008). Interception loss from vegetation canopies $\left(E_{\mathrm{I}}\right)$ is considered a function of potential evapotranspiration (PET after Priestley-Taylor), canopy wetness, vegetation type and precipitation regime. Transpiration $\left(E_{\mathrm{T}}\right)$ is constrained either by PET (modulated by the boundary-layer state) or by soil water supply and plant hydraulic traits, with an additional influence of the vegetation's LAI and both physiological and structural effects of ambient $\mathrm{CO}_{2}$ concentration (Gerten et al., 2007; Fader et al., 2010). Soil evaporation $\left(E_{S}\right)$ is calculated as a function of PET, water content of the upper soil layer, daily phenological status and fractional area covered by a CFT. Total water consumption (evapotranspiration $E$ ) of a CFT is given by the CFT-specific sum of $E_{\mathrm{I}}, E_{\mathrm{T}}$ and $E_{\mathrm{S}}$. Note that we consider each of these components to have a green (GE) and a blue (BE) water constituent, such that for each CFT and day:

$$
E=\mathrm{GE}_{\mathrm{I}}+\mathrm{BE}_{\mathrm{I}}+\mathrm{GE}_{\mathrm{T}}+\mathrm{BE}_{\mathrm{T}}+\mathrm{GE}_{\mathrm{S}}+\mathrm{BE}_{\mathrm{S}}
$$

The separation into green and blue constituents relies in the case of $E_{\mathrm{I}}$ on the shares of irrigation water supply and precipitation on the field and in the case of $E_{\mathrm{T}}$ and $E_{\mathrm{S}}$ on the shares of blue and green water stocks in the soil (for the detailed calculation procedure see Rost et al., 2008). On rainfed areas $E$ only consists of green water (i.e. $\mathrm{BE}=0$ ), whereas on irrigated areas, $E$ consists of both $\mathrm{GE}$ and $\mathrm{BE}$. Figure 1 gives an overview of the computation procedure.

For each CFT blue (BVWC), green (GVWC) and total VWC (all in $\mathrm{m}^{3} \mathrm{~kg}^{-1}$ ) were computed based on the CFT's yield and the three evapotranspiration components as follows.

$$
\begin{aligned}
& \mathrm{BVWC}=\frac{\frac{\mathrm{BE}_{\mathrm{Irr}}}{Y_{\mathrm{Irr}}} \cdot F_{\mathrm{Irr}}}{F_{\mathrm{Ra}}+F_{\mathrm{Irr}}} \\
& \mathrm{GVWC}=\frac{\frac{\mathrm{GE}_{\mathrm{Ra}}}{Y_{\mathrm{Ra}}} \cdot F_{\mathrm{Ra}}+\frac{\mathrm{GE}_{\mathrm{Irr}}}{Y_{\mathrm{Irr}}} \cdot F_{\mathrm{Irr}}}{F_{\mathrm{Ra}}+F_{\mathrm{Irr}}}
\end{aligned}
$$

$\mathrm{VWC}=\mathrm{BVWC}+\mathrm{GVWC}$

where $Y_{\mathrm{Ra}}$ and $Y_{\mathrm{Irr}}$ are the CFT-specific yields (in g dry matter per $\mathrm{m}^{2}$ ) of rainfed and irrigated areas, respectively. $F_{\mathrm{Ra}}$ $\left(F_{\text {Irr }}\right)$ represents the rainfed (irrigated) fraction of the grid cell covered by the CFT.

\subsection{Virtual water and land flows}

As a first step to compute the virtual water flows and water footprints, BVWC, GVWC and VWC values were 
aggregated for each country using a weighted average of the individual grid cell's values accounting for the different areas of a CFT (rainfed and irrigated) and the absolute grid cell size. The thus derived values were then combined with the amount of agricultural commodities traded between countries (derived from COMTRADE).

The green and blue virtual water export from a country $\mathrm{C}$ was computed taking into account the national average CFTspecific values of BVWC and GVWC:

$\mathrm{BVWE}_{\mathrm{C}}=\sum_{\mathrm{CFT}=1}^{11} \mathrm{Ex}_{\mathrm{C}, \mathrm{CFT}} \cdot \mathrm{BVWC}_{\mathrm{C}, \mathrm{CFT}}$

$\mathrm{GVWE}_{\mathrm{C}}=\sum_{\mathrm{CFT}=1}^{11} \mathrm{Ex}_{\mathrm{C}, \mathrm{CFT}} \cdot \mathrm{GVWC}_{\mathrm{C}, \mathrm{CFT}}$

$\mathrm{VWE}_{\mathrm{C}}=\mathrm{GVWE}_{\mathrm{C}}+\mathrm{BVWE}_{\mathrm{C}}$

where Ex is the export $(\mathrm{kg})$ of CFT products, being BVWE the blue, GVWE the green, and VWE the total virtual water export (all in $\mathrm{m}^{3}$ ). (Note that due to the lack of data indicating which proportion of exports has actually been produced in $\mathrm{C}$ and which proportion represents re-exports from other countries, this study assumes that all exported commodities were produced in $\mathrm{C}$. If COMTRADE indicates that $\mathrm{C}$ exports goods which are not produced in that country according to LPJmL and its underlying land use dataset, these exports are not taken into account. If COMTRADE indicates that $\mathrm{C}$ exports more than it produces according to LPJmL, the export amount is reduced to fit the simulated production.)

Analogous to the above calculations, the virtual water import of a country $\mathrm{C}$ was separated into a green and a blue share, taking into account the ex situ, CFT-specific values of BVWC and GVWC of each country $i$ from which it receives the imported goods:

$\mathrm{BVWI}_{\mathrm{C}}=\sum_{\mathrm{CFT}=1}^{11} \sum_{i=1}^{n} \operatorname{Im}_{\mathrm{C}, \mathrm{CFT}, i} \cdot \mathrm{BVWC}_{\mathrm{CFT}, i}$

$\mathrm{GVWI}_{\mathrm{C}}=\sum_{\mathrm{CFT}=1}^{11} \sum_{i=1}^{n} \mathrm{Im}_{\mathrm{C}, \mathrm{CFT}, i} \cdot \mathrm{GVWC}_{\mathrm{CFT}, i}$

$\mathrm{VWI}_{\mathrm{C}}=\mathrm{GVWI}_{\mathrm{C}}+\mathrm{BVWI}_{\mathrm{C}}$

where Im are the imports to C (in kg), and BVWI, GVWI and VWI are the blue, green and total virtual water imports, respectively (all in $\mathrm{m}^{3}$ ). $\mathrm{VWI}_{\mathrm{C}}$ depends not only on the amount of commodities imported by $\mathrm{C}$ but also on the products' ex situ VWC of the countries $i$ exporting to it. Analogously, VWE depends on both the amount of commodities exported by $\mathrm{C}$ and its in situ VWC values. High values of VWI and VWE can thus result from intensive trade flows, high VWC values, or a combination of both.
The net balance of country $\mathrm{C}$ for green (GVWB), blue (BVWB) and total (VWB) virtual water $\left(\right.$ in $\mathrm{m}^{3}$ ) was calculated as:

$$
\begin{aligned}
& \mathrm{BVWB}_{\mathrm{C}}=\mathrm{BVWI}_{\mathrm{C}}-\mathrm{BVWE}_{\mathrm{C}} \\
& \mathrm{GVWB}_{\mathrm{C}}=\mathrm{GVWI}_{\mathrm{C}}-\mathrm{GVWE}_{\mathrm{C}} \\
& \mathrm{VWB}_{\mathrm{C}}=\mathrm{GVWB}_{\mathrm{C}}+\mathrm{BVWB}_{\mathrm{C}}
\end{aligned}
$$

Hence, negative values indicate that $\mathrm{C}$ is a net exporter of virtual water, and vice versa. Note that VWB depends on the imported and exported amount of commodities, the countryinternal VWC, and the ex situ VWC of the countries $i$ exporting to $\mathrm{C}$.

In order to demonstrate the significance of the virtual water exports, we set VWE in relation to the country's current water consumption ( $E$ of the 11 CFTs considered here).

A combination of the CFT-specific average yield per country and its export/import amounts gives an idea of the land area that is used for producing the exported goods and the "virtual land" imported from other countries:

$$
\begin{aligned}
\mathrm{VLE}_{\mathrm{C}} & =\sum_{\mathrm{CFT}=1}^{11} \frac{\mathrm{Ex}_{\mathrm{C}, \mathrm{CFT}}}{\bar{Y}_{\mathrm{C}, \mathrm{CFT}}} \\
\mathrm{VLI}_{\mathrm{C}} & =\sum_{\mathrm{CFT}=1}^{11} \sum_{i=1}^{n} \frac{\mathrm{Im}_{\mathrm{C}, \mathrm{CFT}, i}}{\bar{Y}_{\mathrm{CFT}, i}} \\
\mathrm{VLB}_{\mathrm{C}} & =\mathrm{VLI}_{\mathrm{C}}-\mathrm{VLE}_{\mathrm{C}}
\end{aligned}
$$

where VLE and VLI are the virtual land export and import, respectively, and VLB is the virtual land balance (all in ha). Negative values of VLB represent a net export of virtual land, while positive values represent a net import. To put into perspective the virtual land exports, we calculated for each country the ratio of VLE to the country's cropland area.

\subsection{Internal and external green and blue water footprints}

The internal water footprint of a country $\left(\mathrm{IWFP}_{\mathrm{C}}\right)$ is the amount of water consumed (evapotranspired) in that country to produce the food consumed by its inhabitants (i.e. the total crop water consumption minus the virtual water export, see Eq. 17), assuming no changes in stock of agricultural commodities. Analogously, the external water footprint of a country $\left(\mathrm{EWFP}_{\mathrm{C}}\right)$ is the water consumed in other countries to produce the food consumed in C. IWFP and EWFP - either in $\mathrm{km}^{3}$ or $\mathrm{m}^{3} \mathrm{cap}^{-1}$, depending on whether the footprint was computed per country or per person - both have a green and a blue component, respectively.

$\mathrm{BIWFP}_{\mathrm{C}}=\frac{\sum_{\mathrm{CFT}=1}^{11}\left(\mathrm{BE}_{\mathrm{C}, \mathrm{CFT}}-\mathrm{BVWE} \mathrm{C}, \mathrm{CFT}\right)}{\text { Pop }}$ 


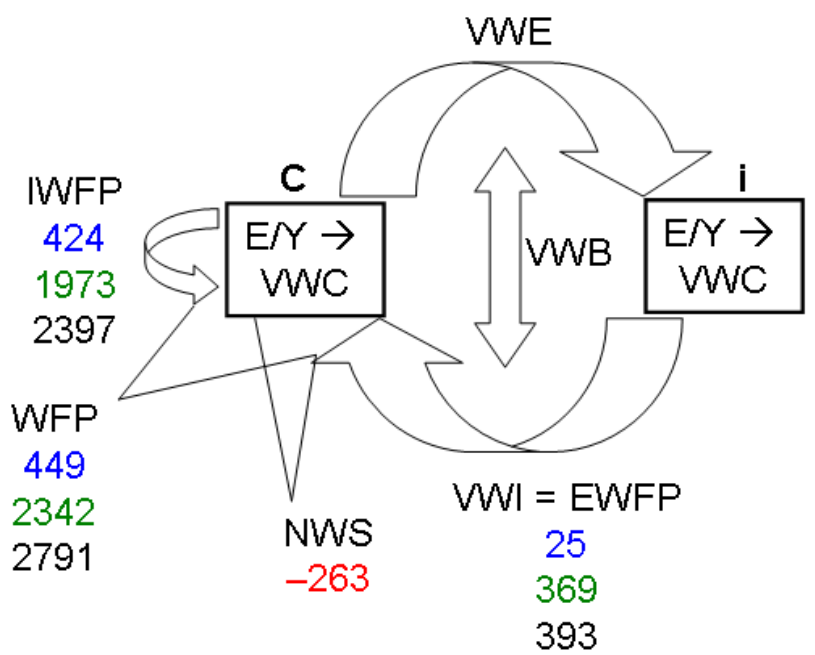

Fig. 1. Overview of the water flows illustrated for countries $\mathrm{C}$ and i (see Methods) and total global values of blue (in blue), green (in green) and total (in black) water footprints as well as net water savings (in red). All values are in $\mathrm{km}^{3}$ and represent sums over the 11 CFTs included in this study averaged for the period 19982002. Note that the global VWE equals the global VWI, and that the global VWB is zero. Global water and land productivity are implicitly increased through trade by $8 \%$ and $5 \%$, respectively (see Results).

BIWFP is the blue internal water footprint, and Pop is here the population of $\mathrm{C}$ after Grübler et al. (2007). The green internal water footprint (GIWFP) was computed analogously. The total IWFP is the sum of BIWFP and GIWFP. The blue $\left(\right.$ BEWFP $\left._{C}\right)$ and green external water footprints $\left(\right.$ GEWFP $\left._{C}\right)$ equal the country's BVWI and GVWI, respectively (see Eqs. 8 and 9), and they were also computed per capita. The total external water footprint EWFP is given by the sum of BEWFP and GEWFP.

Finally, the total blue water footprint (BWFP) of a country is the sum of BIWFP and BEWFP; the total green water footprint (GWFP) the sum of GIWFP and GEWFP; and the total water footprint (WFP) the sum of EWFP and IWFP or of BWFP and GWFP (Fig. 1).

By means of computing the absolute footprints (i.e. without the division by population), the total global green and blue agricultural water footprints were calculated as the sum of the national GWFP and BWFP values, respectively.

\subsection{Water and land savings}

By importing agricultural goods, a country "saves" the water and land that it would have needed to produce them. Correspondingly, if a country would decide to avoid imports of agricultural goods (e.g. in order to reduce dependency on other countries or to promote inland agriculture), it would have to use own land and water for this production. We com- puted such savings as the amount of water (WS, green and blue combined, in $\mathrm{m}^{3}$ ) and the land area (LS, in ha) that a country would have needed to produce the imported crops on its own territory.

$$
\begin{aligned}
& \mathrm{WS}_{\mathrm{C}}=\sum_{\mathrm{CFT}=1}^{11} \sum_{i=1}^{n} \operatorname{Im}_{\mathrm{C}, \mathrm{CFT}, i} \cdot \mathrm{VWC}_{\mathrm{C}, \mathrm{CFT}} \\
& \mathrm{LS}_{\mathrm{C}}=\sum_{\mathrm{CFT}=1}^{11} \sum_{i=1}^{n} \frac{\operatorname{Im}_{\mathrm{C}, \mathrm{CFT}, i}}{\bar{Y}_{\mathrm{C}, \mathrm{CFT}}}
\end{aligned}
$$

If the product analysed is not produced in the importing country, the CFT-specific global means for $Y$ and VWC were used for the calculations. Note that the definition of water needs/savings WS differs from that of VWI (see Eq. 10), in that here the in situ VWC of the importing country $\mathrm{C}$ is used, while VWI is based on the ex situ VWC of the export country $i$.

Considering that, in turn, the agricultural areas cultivated for growing the exported products would be abandoned and left for natural vegetation or other non-cropland uses, we also quantified the water volumes (WR, in $\mathrm{m}^{3}$ ) and land areas (LR, in ha) that would be released this way as the amounts consumed for the production of exported goods. WR and LR equal the sum of virtual water and land exports from C (as computed by Eqs. 7 and 14), respectively.

We furthermore subtracted the water and land savings from WR and LR, respectively:

$$
\begin{aligned}
& \mathrm{NWS}_{\mathrm{C}}\left[\mathrm{m}^{3}\right]=\mathrm{WR}_{\mathrm{C}}-\mathrm{WS}_{\mathrm{C}} \\
& \mathrm{NLS}_{\mathrm{C}}[\mathrm{ha}]=\mathrm{LR}_{\mathrm{C}}-\mathrm{LS}_{\mathrm{C}}
\end{aligned}
$$

where NWS is the net water saving of country $\mathrm{C}\left(\mathrm{km}^{3}\right)$ and NLS its net land saving (ha). Negative values mean that the water or land that would be required for own production of imported goods is higher than the water or land that would be released in that country through avoided production of export goods, i.e. negative values imply net savings and positive values imply net losses through current trade.

Taking into account that $Y$ and thus VWC vary strongly among countries, we also address the question whether globally the water and land resources that a world of selfsufficient countries would consume exceeds, or falls below, the resources consumed under current trade patterns. These global water and land savings or losses are represented by the sum of each country's net savings. Negative values of this global indicator suggest that producing the import goods in the own territories would consume globally more water/land than is the case under current trade patterns. We then related the countries' land/water savings and net savings to the current water consumption of the studied CFTs $(E)$ and the (sowing) area they cover, respectively.

Finally, we investigated if the global water and land productivities (i.e. VWC and $Y$ ) were increased or decreased by 
Table 1. Rank of the top 5 net importers and net exporters for blue, green and total water.

\begin{tabular}{ll}
\hline Rank (descending) & \\
\hline BLUE & \\
\hline Japan & Net \\
Indonesia & Importers \\
North Korea & \\
Bangladesh & \\
Papua New Guinea & \\
\hline United States & Net \\
India & Exporters \\
Thailand & \\
China & \\
Pakistan & \\
\hline GREEN & \\
\hline Japan & Net \\
Mexico & Importers \\
The Netherlands & \\
North Korea & \\
Spain & \\
\hline United States & Net \\
Argentina & Exporters \\
Australia & \\
Canada & \\
France & \\
\hline TOTAL & \\
\hline Japan & \\
Mexico & \\
North Korea & Net Netherters \\
The Netherlands & \\
\hline United States & \\
Argentina & \\
Australia & \\
France & \\
\hline & \\
\hline
\end{tabular}

international trade. This was done by comparing global estimates of VWC and $Y$ in a world of self-sufficient countries and under current trade patterns.

\section{Results}

The following sections describe our results for virtual water contents, flows, footprints and savings as well as virtual land flows and savings. A detailed comparison of these results with previous studies can be found in Appendix A.

\subsection{Blue and green virtual water contents}

As shown in Fig. 2, values of both BVWC and GVWC demonstrate a pronounced regional pattern. Especially GVWC is significantly higher across the Southern Hemi- sphere and large parts of Asia than in Western and Central Europe and most of North America. While part of this regional discrepancy is attributable to differences in climatic and biophysical conditions, the main reason is differences in agricultural management intensity. As detailed in the study by Fader et al. (2010), VWC is high in poorly managed regions with low yields, whereas it is low in regions with favourable biophysical conditions and intensive agricultural management including irrigation. In most regions where irrigated and rainfed agriculture coexist, GVWC appears to be higher than BVWC, as vegetation grows faster and uses water more effectively in irrigated fields with continuous blue water supply; differences in sowing dates and phenological development also play a role. Similarly, both BVWC and GVWC also differ among coexisting CFTs (see Fader et al., 2010 for temperate cereals and maize). As discussed in Appendix A, our values of BVWC and GVWC are in line with the few other estimates that are available.

\subsection{Virtual water and land flows}

As explained above, green and blue water need to be analysed separately due to different sources, opportunity costs, tradeoffs and environmental implications of their use. Thus, it is interesting to know if the traditional exporters/importers are trading mainly green or blue water, or if a country even has contrary balances depending on the type of water considered.

Figure 3a shows that the US, India, Thailand, China and Pakistan are significant net exporters of blue virtual water (negative value of BVWB). In contrast, countries such as Japan, Indonesia, North Korea and Bangladesh - and to a lesser extent also a number of countries in Europe, Africa and the Americas - turn out to be net importers of blue virtual water. As expected, rice imports and exports generally shape the blue virtual water balances.

The US, Argentina, Australia, Canada and France are, according to our calculations for the considered CFTs, the countries with the highest negative balances of green water, mainly due to exports of wheat. Japan, Mexico, The Netherlands, North Korea and Spain are the largest net green virtual water importers (see Fig. 3b), basically due to imports of wheat, maize and soybeans.

Interestingly, Spain, Italy and China are net blue water exporters but net green water importers and Brazil is a net blue water importer but a net green water exporter.

The total virtual water balance (VWB) suggests that the US, Argentina, Australia, Canada and France are the largest net virtual water exporters of the CFTs considered here, whereas Japan, Mexico, North Korea, The Netherlands and Spain are the major net virtual water importers (see Table 1). While the net virtual water exporters export large quantities to many countries around the world, the net virtual water importers obtain the goods - thus the virtual water - mainly from the US, China, Argentina, Australia and Canada. 


\section{a. Blue virtual water content (BVWC)}

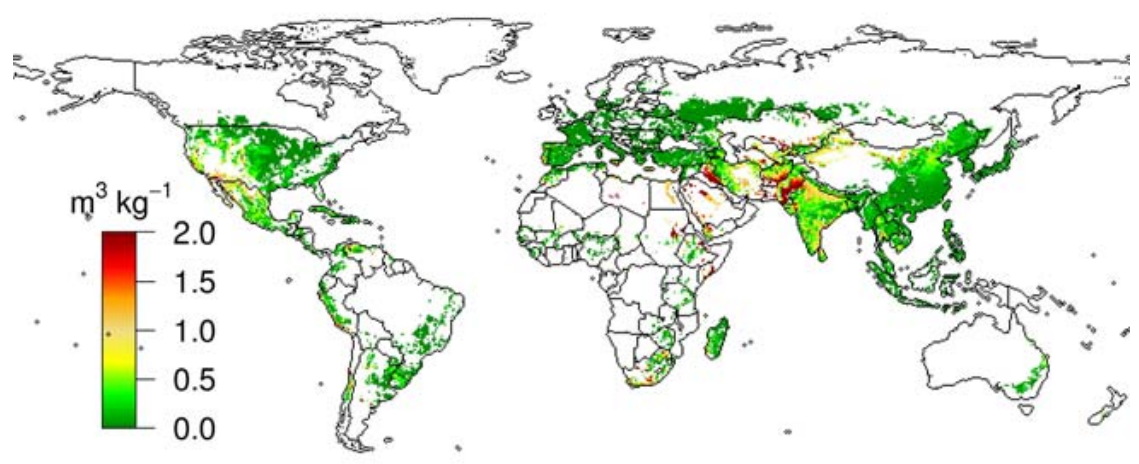

\section{b. Green virtual water content (GVWC)}

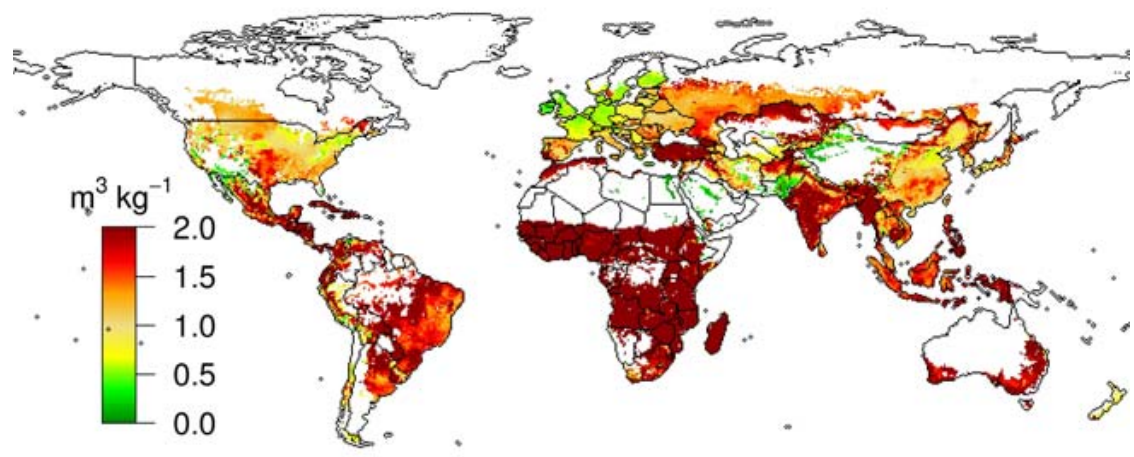

Fig. 2. LPJmL-simulated blue (a) and green (b) virtual water content shown as average over all CFTs, $1998-2002$ period and $0.5^{\circ}$ resolution.

Paraguay, Argentina, Uruguay and Canada use more than $50 \%$ of their current (green and blue) water consumption to produce export goods; in the case of Australia, Cyprus and Oman it is more than $70 \%$ (data not shown).

Even if many net virtual water importers are water-scarce countries (compare UNEP, 2008 or Gerten et al., 2011, who show North Africa and large parts of Asia to be water-scarce, stressed or vulnerable), the top five net importers and others (such as the Andean countries) are characterized by a water availability of $>2500 \mathrm{~m}^{3} \mathrm{cap}^{-1} \mathrm{yr}^{-1}$. Almost all net virtual water exporters appear to have abundant water resources, with the exception of India, Pakistan and South Africa (UNEP, 2008). These results point out that VWB are frequently co-determined by factors other than water (Yang et al., 2003).

Concerning the VLB (Fig. 3c), i.e. the virtual land imports minus the virtual land exports, the US, Canada, Argentina and Australia are net virtual land exporters, while many countries in Southeast Asia and around the Mediterranean Sea are net virtual land importers. Guyana, Suriname, Cyprus, Australia, Luxemburg and Canada use $>70 \%$ of their cropland to produce export goods (data not shown). Net virtual land exporters are in general large countries; however, not only the total area is relevant, but also the fertility of the soil and the slope. This could partly explain the fact that France and Thailand are net virtual land exporters, and China a net virtual land importer (compare maps on terrain slopes and soil resources from e.g. IIASA and FAO, 2000).

The patterns of VLB are very similar to the patterns in VWB; at country level Pearson's correlation coefficient between both is 0.98 . This demonstrates that virtual water flows are linked with virtual land flows; this is especially true for green water flows due to their correlation with the size of the area under cultivation. See Appendix A (and Table A2) for a discussion of how our estimates of virtual land/water flows relate to other studies.

\subsection{Water footprints per country and per capita}

The blue and green agricultural water footprints quantified here exhibit pronounced differences among countries. Also, there are substantial differences between (blue and green) internal and external water footprints, and they show a different pattern depending on whether they are calculated per country or per capita, as detailed in the following. 


\section{a. Blue virtual water balance (BVWB)}

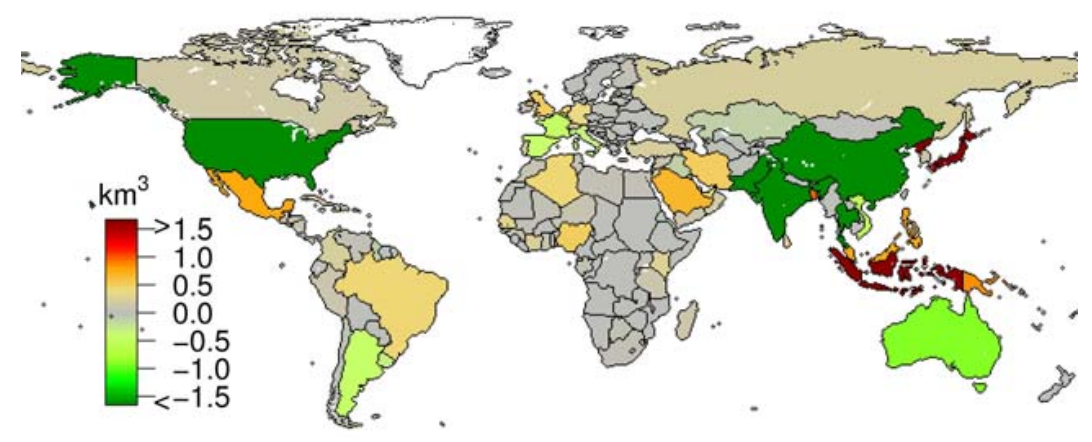

\section{b. Green virtual water balance (GVWB)}

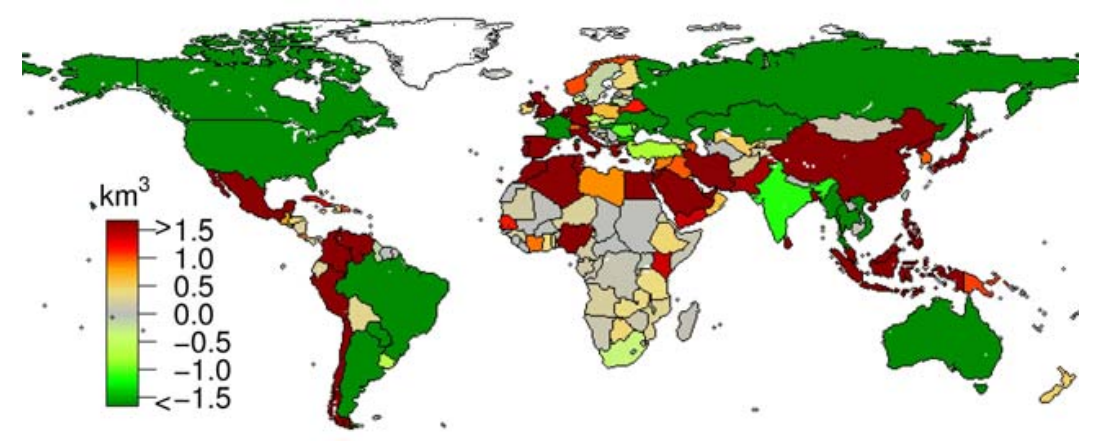

\section{c. Virtual land balance (VLB)}

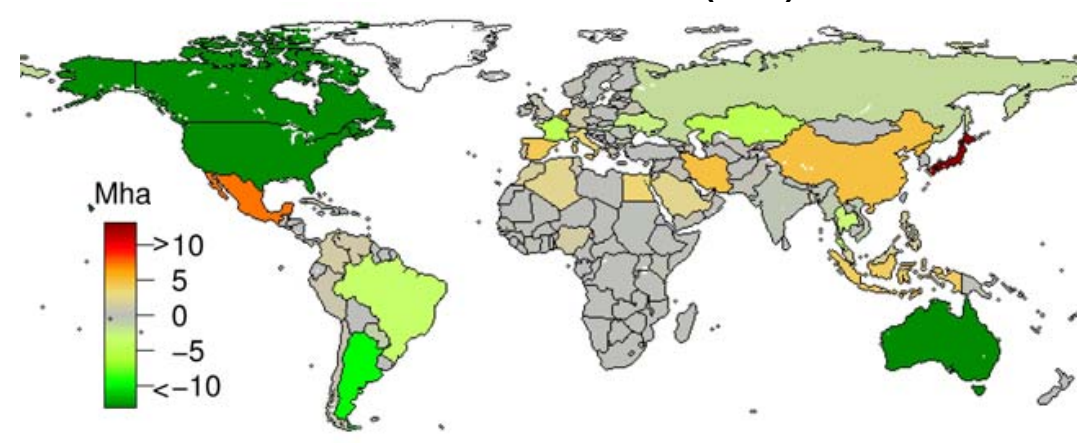

Fig. 3. Countries' net virtual water and land balances for the 11 CFTs considered. Negative (positive) values indicate a net export (import) of virtual water or land. All values represent the means of the period 1998-2002.

\subsubsection{Internal, external and total blue water footprints}

Figure 4 (top left) shows the total BWFP computed at country scale, i.e. the blue water evapotranspired in a country $\mathrm{C}$ for producing the 11 considered CFTs consumed in $\mathrm{C}$ and the blue water evapotranspired in other countries for producing the commodities exported to $\mathrm{C}$. The map indicates that BWFP is highest ( $>30$ up to $170 \mathrm{~km}^{3}$ ) for India, China and Pakistan followed by the US $\left(\sim 20 \mathrm{~km}^{3}\right)$, and very low in Europe, South America and Africa. This pattern mainly reflects the BIWFP, as the blue external water footprint (BEWFP) is comparatively low $\left(<1 \mathrm{~m}^{3}\right)$ in most countries (Fig. 4).
The aggregate global blue water footprint of the crop products considered here amounts to $449 \mathrm{~km}^{3}$ (Fig. 1). Of these, only $25 \mathrm{~km}^{3}$ are for exports, according to the low values of BEWFP. Note that this global agricultural BWFP is significantly lower than reported in earlier studies, as we consider only part of the cropland here. Including the collectively parameterised "other crops" would yield a global BWFP close to other estimates $\left(923 \mathrm{~km}^{3}\right.$; see Appendix A). Rice, temperate cereals and maize alone make up about $87 \%\left(390 \mathrm{~km}^{3}\right)$ of global BWFP in our study (data not shown).

When computing the water footprints on a per capita basis, the spatial patterns differ significantly compared to those 

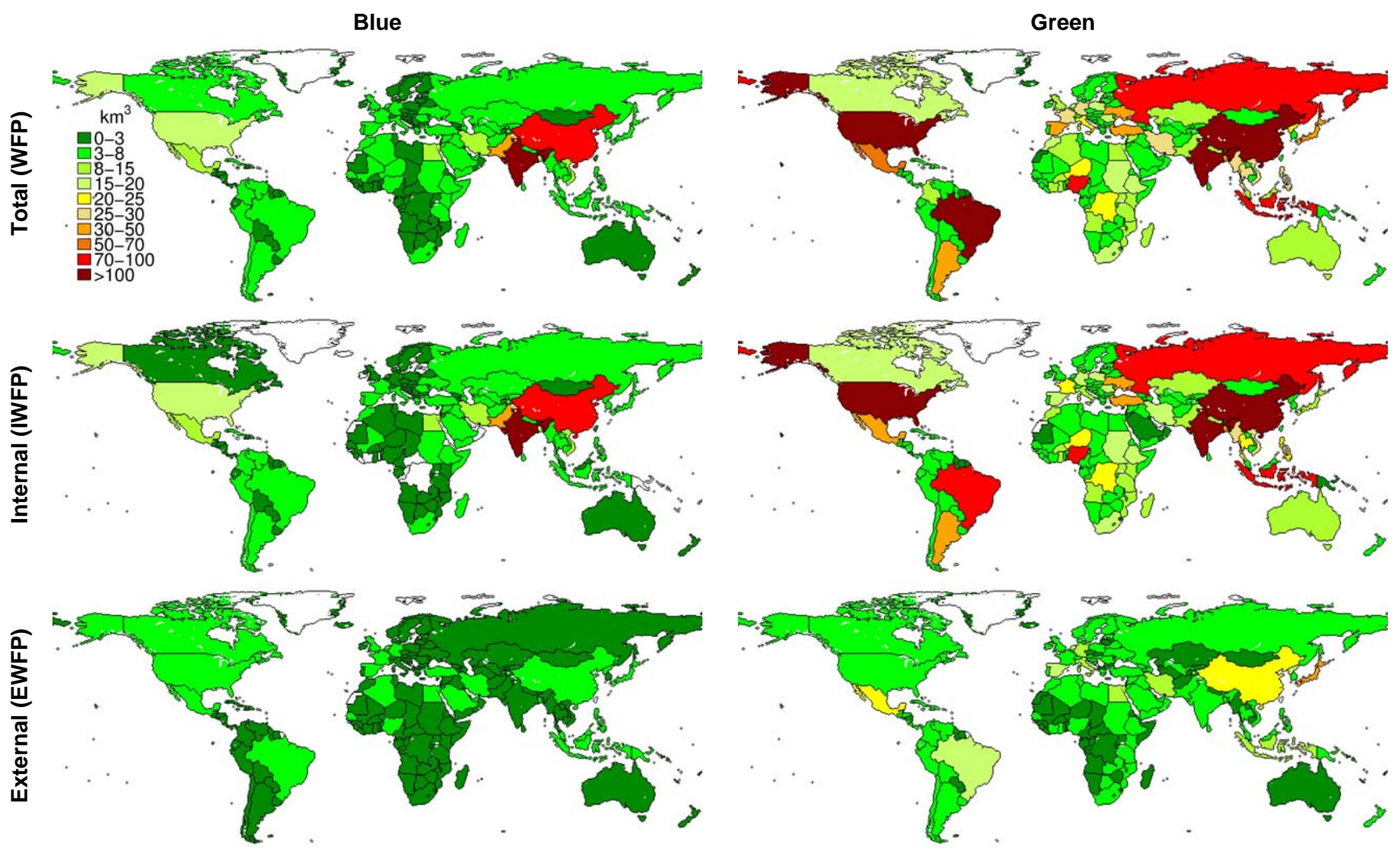

Fig. 4. Internal, external and total blue and green water footprints per country for all CFTs, 1998-2002 average.

computed at country scale. Figure B1 in Appendix B shows that the per capita total BWFP is highest in most countries in the Near East (up to $\sim 300 \mathrm{~m}^{3} \mathrm{cap}^{-1}$ ). Countries such as Mexico, India, Pakistan and the US also show relatively high per capita values of BWFP, as in the case of the country-based values. Again, this pattern basically reflects that of BIWFP, while values of BEWFP are mostly very low, i.e. $<30 \mathrm{~m}^{3} \mathrm{cap}^{-1}$ (Fig. B1), with notable exceptions of $>100 \mathrm{~m}^{3} \mathrm{cap}^{-1}$ like for the United Arab Emirates, Papua New Guinea, and others.

\subsubsection{Internal, external and total green water footprints}

The total green water footprint of countries GWFP is highest ( $>100$ up to $318 \mathrm{~km}^{3}$ ) for China, India, the US and Brazil and lowest for many African and South American countries (Fig. 4, right panel). As in the case of blue water, this mainly reflects the pattern of the green internal water footprint GIWFP, though the external green water footprint (GEWFP) is also high for some countries, especially for Japan, Mexico, China and The Netherlands.

The global GWFP amounts to $2342 \mathrm{~km}^{3}$ (including $369 \mathrm{~km}^{3}$ for export goods, GEWFP; see Fig. 1), thus representing $84 \%$ of total crop water consumption. This percentage value confirms the estimates by Liu et al. (2009) and
Liu and Yang (2010) for a similar sets of crops and the same time frame, but the absolute value is lower than found in earlier studies (Rost et al., 2008: $7242 \mathrm{~km}^{3}$; Liu et al., 2009: $3103 \mathrm{~km}^{3}$; Siebert and Döll, 2010: $5731 \mathrm{~km}^{3}$; Hoff et al., 2010: $4975-5731 \mathrm{~km}^{3}$ ). However, our estimate including the "other crops" yields $5978 \mathrm{~km}^{3}$, which is of the same order than the above estimates. Maize, temperate cereals and rice are the main consumers of green water as in the case of blue water, but the contributions of tropical cereals, pulses and soybean are higher (data not shown; see Appendix A for some CFT-specific comparisons with other studies).

On a per capita basis, GWFP (and also GIWFP, see Fig. B1) exceed $1000 \mathrm{~m}^{3} \mathrm{cap}^{-1}$ in countries such as Niger, the Central African Republic and Argentina, and values are lower in many Andean and African countries as well as in China and India (Fig. B1). The GEWFP is generally lower than the GIWFP but relatively high (from 750 up to $1100 \mathrm{~m}^{3} \mathrm{cap}^{-1}$ ) in the Netherlands, Cyprus, the United Arab Emirates and Israel.

Globally, both production and export of agricultural goods are dominated by green water: $84 \%$ of the global water consumption is green, and $94 \%$ of the total water used for the production of export goods is green, as many important exporters produce mainly under rainfed conditions. 


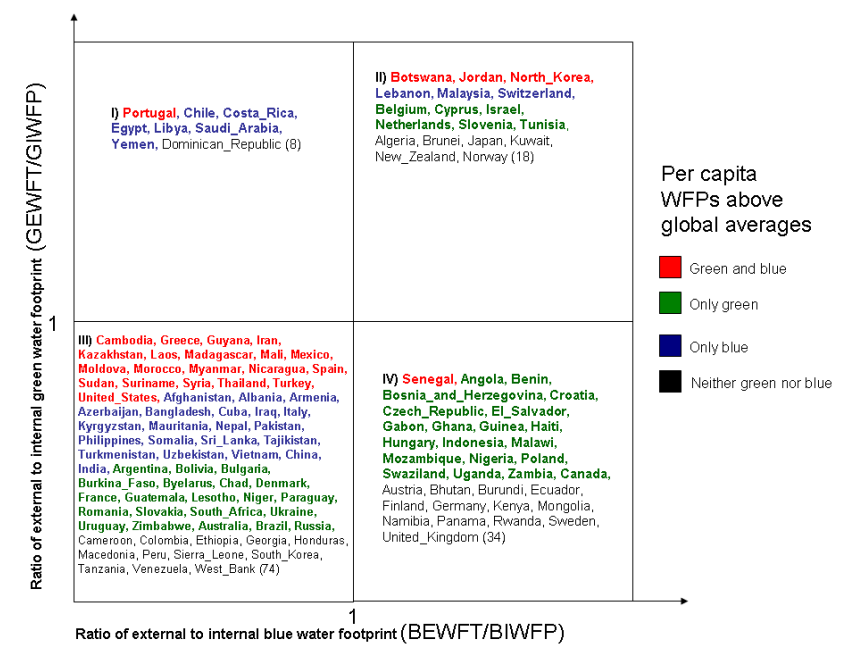

Fig. 5. Classification of countries after their blue and green ratios of external to internal WFPs. Countries with values $>1$ on the $\mathrm{x}(\mathrm{y})$ axis consume more blue (green) water from other countries than from the own country. For countries coloured in red, BWFP and GWFP per capita exceed the respective global average; blue, only BWFP > global average BWFP; green, only GWFP > global average GWFP; black, BWFP and GWFP < respective global average. Numbers in parentheses at the end of the lists represent the total number of countries in the corresponding quadrant.

The share of blue and green water consumed for export goods is relatively low ( $6 \%$ of the total blue water consumption is for export goods, and $16 \%$ of the total green water consumption is for export goods, Fig. 1). Only a couple of islands are shown to have a BEWFP to GEWFP ratio $>1$ (data not shown).

\subsubsection{Linkages between high WFPs and EWFPs}

In order to assess to what extent countries with high WFPs obtain virtual water from abroad, we related the external to internal WFP ratios to the WFPs per capita (see Fig. 5).

A total of 52 countries, including many countries in Europe, insular Asia and Africa, have a ratio BEWFP to BIWFP $>1$, meaning that they consume more blue water from abroad than from their own territory (quadrants II and IV). This is not due to the fact that a lot of them import high amounts of virtual blue water since most do not have BWFP per capita above average, with the exception of Lebanon, Malaysia and Switzerland. The reason is that the agriculture in these countries is based on green water, the consumption of own blue water thus being very low. This is also shown in the predominance of green colours in the quadrant IV (representing above average GWFP). Nevertheless, countries in the quadrants II and IV present to a certain degree a dependency on blue water imports.

Some Andean countries as well as countries around the Mediterranean Sea consume more green water from abroad than from their own resources, suggesting a certain dependency on green water imports (quadrants I and II). This is mainly due to low precipitation (i.e. lack of green water, partly also reflecting small cropland areas) as shown by the lack of green colours especially in quadrant I. The countries in quadrant II consume more blue and green water abroad than in the own territories, but not every one of them has WFPs above average.

Most countries are in the quadrant III, indicating that they consume more green and blue water on the own territory than abroad. Nevertheless many of them present above average WFPs (green, blue or both).

In short: countries with high levels of per capita water consumption affect mainly the water availability in the own country.

\subsection{Water and land savings related to trade}

\subsubsection{Water savings}

As shown in Fig. 6a, some water-scarce countries, such as China and Mexico but also The Netherlands and Japan would need relatively high amounts of water to produce the goods they import, i.e. they save high amounts of water by importing goods (WS $>25$ up to $73 \mathrm{~km}^{3}$ ). Putting these savings into the context of current green-blue water consumption (of the 11 CFTs) demonstrates that many countries - 39 in total, especially in North Africa and Latin America - would have to more than double their water consumption to produce their imports on the own territory (Fig. 6b).

The net water savings NWS (computed with Eq. (20) and shown in Fig. 6c) indicate that the US, Canada, Argentina and Australia would, as a net result, release water (up to $112 \mathrm{~km}^{3}$ ) if they produced the imported agricultural goods on their own and did not export any goods. This means that these countries could hypothetically maintain the current consumption of agricultural goods and at the same time allocate part of the water used currently for the agricultural export sector to other uses, including natural ecosystems. The opposite is true for e.g. Japan, Mexico and The Netherlands (NWS $<0$ ). These countries would need to use more water (up to $72 \mathrm{~km}^{3}$ in Japan) in their agricultural sectors if they stopped importing and exporting agricultural products. Overall, there are many more such countries with a negative NWS than countries with a positive one (162 vs. 23). Relating NWS to the current water consumption E reveals that some net exporters, such as Argentina, Canada and Australia, could allocate $>50 \%$ of $\mathrm{E}$ for other purposes if there was no trade (Fig. 6d). By contrast, many net importers would have to strongly increase $E$.

Globally, current trade of the crop products considered here saves $263 \mathrm{~km}^{3}$ of green and blue water (Fig. 1), or in other words, a world of self-sufficient countries under current consumption patterns would need this amount in addition to maintain the current levels of agricultural 
a. Water saved (WS)

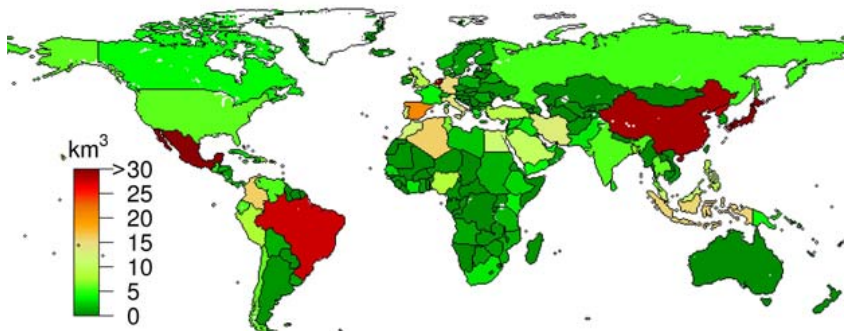

c. Net water savings (NWS)

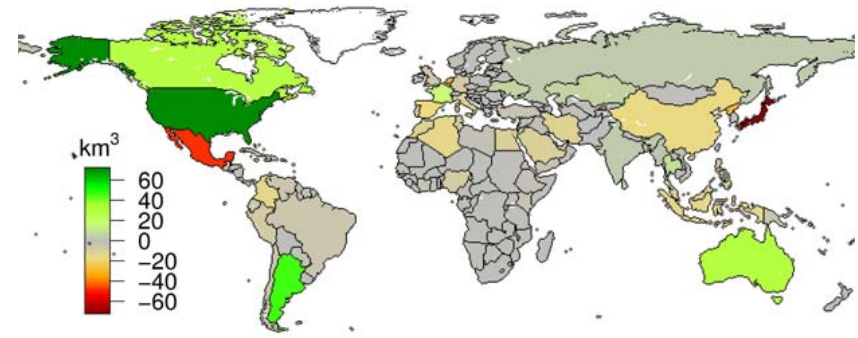

b. WS relative to current water consumption

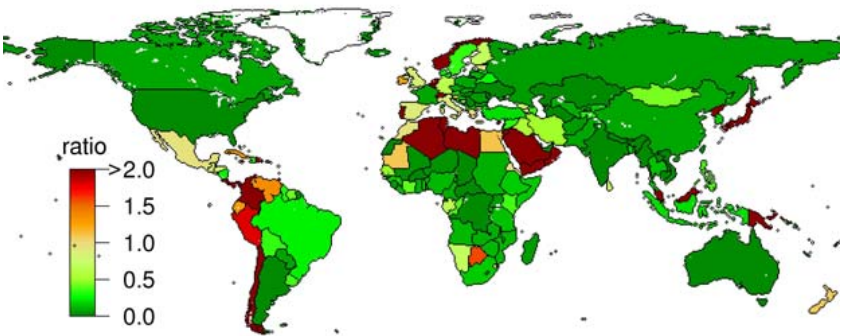

d. NWS relative to current water consumption

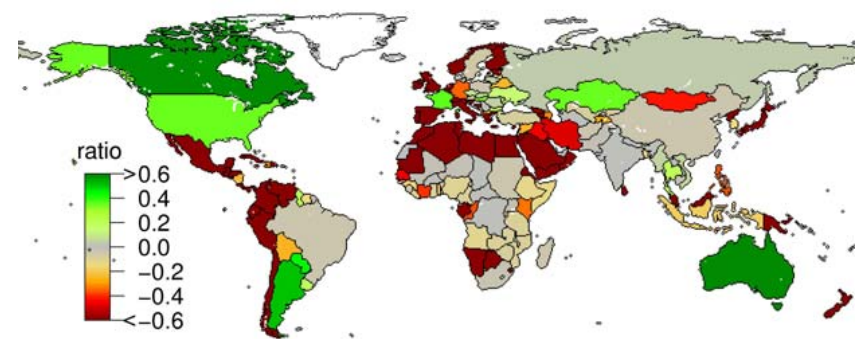

Fig. 6. (a) Green plus blue water volumes (WS in $\mathrm{km}^{3}$ ) that would be required in a country's own territory for the production of imports (i.e. water saved through imports), (b) WS relative to current water consumption $E$ (values $>1$ indicate that own production of imports would need an amount of water more than double the present amount), (c) net water savings NWS, i.e. WR-WS, and (d) NWS relative to $E$. (Negative values in (c) and (d) indicate the need for consuming more water for crop production in case of no international trade).

production/consumption. This amount represents $\sim 0.2 \%$ of the global annual precipitation and $3.5 \%$ of the annual precipitation on cropland.

Water productivity at global level is $8 \%$ higher (i.e. VWC $8 \%$ lower) under current trade patterns than would be the case in a world of self-sufficient countries. However, the CFT-specific values were very different: pulses, temperate roots and groundnuts show values $<1 \%$, tropical roots, rapeseed, tropical cereals, rice and sunflower values between $1 \%$ and $\leq 5 \%$, and temperate cereals, maize and soybeans values $>9 \%$ up to $16 \%$.

\subsubsection{Land savings}

Considering the land needed (LS) in order to produce imports goods on the own territory, i.e. the land saved for other uses, China and Mexico would need 9 Mha, North Korea and The Netherlands $\sim 7$ Mha each, and Japan $>$ 16 Mha (Fig. 7a). Relating these needs to the current cropland extent demonstrates that many countries - 40 in total, especially in North Africa and Latin America - would have to more than double the current cropland to produce their imports on the own territory (Fig. 7b).

The NLS as computed from Eq. (21), i.e. the additional land a country would have to use or the land a country would release for other uses in case of avoiding trade is shown in Fig. 7c. The patterns are very similar to the NWS (Fig. 6c), with e.g. North America, Argentina and Australia being able to release land (around 14 Mha for Australia and Canada and 35 Mha for the US) and parts of Africa and many countries in
Europe, South America and Asia having to occupy additional land to produce what they currently import, e.g. 7-8 Mha for The Netherlands, North Korea and Mexico and 16 Mha for Japan (Fig. 7c). At country level the correlation coefficient between NWS and NLS is 0.96, suggesting that water savings/losses are associated with land savings/losses.

Relating NLS to the current cropland reveals that some net exporters, such as Paraguay, Canada and Australia, could allocate $60-70 \%$ of their current cropland for other purposes if they would not export any goods and produce the present imports on their own. On the contrary, many net importers would have to strongly expand their cropland (Fig. 7d).

Globally, current trade saves $\sim 41$ Mha $(5 \%$ of the area presently occupied for the 11 CFTs considered), suggesting that a world of self-sufficient countries under current consumption patterns would need this land in addition to maintain the current levels of agricultural production/consumption. Current trade also leads to higher global land savings than water savings (at least when these are expressed as percentage of annual precipitation on cropland, see previous section).

Land productivity (i.e. $Y$ ) at global level is $5 \%$ higher under current trade patterns than it would be in a world of selfsufficient countries (CFT-specific values: tropical cereals, temperate roots, sunflowers and rapeseed $<1 \%$; temperate cereals, rice, pulses, tropical roots and groundnuts between $1 \%$ and $\leq 3 \%$; soybeans and maize $16-17 \%$ ). 


\section{Discussion}

\subsection{General findings}

This study presents a process-detailed and spatially explicit differentiation of blue and green water in virtual water contents, virtual water flows and both country-internal and -external agricultural water footprints for the majority (though not all) of the world's crop types. The comprehensiveness of the study is innovative, since former studies were limited by the narrow list of commodities considered, the lack of differentiation (blue vs. green, internal vs. external) or some crude model assumptions (country-scale VWC calculations, neglect of water stress, no consideration of coexistence of crops in a grid cell - see Introduction). As a further novel aspect, it quantifies not only the water savings but also the land savings associated with the international trade of the respective crop products. Our main conclusions are as follows.

1. Green water dominates the production of agricultural goods, both for domestic consumption and for production of export goods: $84 \%$ of the total water consumption for the studied crops is from green water, and $94 \%$ of the external water footprint is constituted by its green water component.

2. Blue and green external water footprints are generally low (for the 11 CFTs, BEWFP $=6 \%$ of BWFP and GEWFP $=16 \%$ of GWFP).

3. No country ranks among the top ten with respect to all water footprints calculated here, but Pakistan and Iran have high absolute and per capita BWFPs, and the US and India high absolute GWFPs and BWFPs.

4. Countries with high WFPs per capita consume mainly water available on their territory (though part of the blue water can stem from upstream countries).

5. International trade globally saves both water and land $\left(\sim 263 \mathrm{~km}^{3}, \sim 41\right.$ Mha for the CFTs considered here).

6. Global water and land productivities are higher under current trade patterns than in a hypothetical world of self-sufficient countries ( $8 \%$ and $5 \%$ respectively).

7. Virtual land flows and savings are intrinsically related to virtual water flows and savings, particularly in the case of green water.

In the following sections we will discuss these main findings, debate on relevant features of the model used, and suggest options for further research to complement and advance the present study.

\subsection{Advances through dynamic and high-resolution crop and water modelling}

As opposed to earlier studies of virtual water trade and water footprints, we employed a global vegetation and water balance model (LPJmL) simulating the dynamic interactions among water consumption (evapotranspiration and its components) in irrigated and rainfed agriculture (and also natural vegetation), the seasonal growth and productivity of different vegetation types under explicit consideration of water stress, and the associated carbon fluxes. Principally, we think that LPJmL can better account for effects of climate variability on crop production, yields and virtual water contents than standalone hydrological models (which usually do not represent crop dynamics at all) or models that use prescribed crop calendars (without accounting for short-term weather, particularly droughts). Apart from the comparisons presented herein (Appendix A), we have carried out more detailed comparisons of LPJmL-simulated total VWC with available sitescale measurements and with estimates from other modelling studies for maize and temperate cereals (wheat) in Fader et al. (2010). In that study we also discussed the difficulties in validating such values given the absence of large-scale observations and the conceptual differences between models used for calculating VWC (and, based on this, VWE and VWI; see below). While the present comparison indicates quite robust results in that the relative differences between the different crop types are similar among the studies, systematic model intercomparisons are required to identify in detail the uncertainties related to model and data characteristics - including the sometimes very large differences in the underlying trade databases. A peculiarity with respect to trade data is that the lack of data concerning re-exports forced us to assume that the exports documented in the COMTRADE database were produced in the exporting country, which inevitably leads to biases in WFPs for countries with exports of goods not produced on their territory.

Of course, the model used here has shortcomings. For example, as in most if not all global hydrological studies, we had to assume that there always is enough blue water available for irrigation in regions equipped for doing so (see Rost et al., 2008). This may lead to an overestimation of blue water consumption and eventually blue water footprints for a few countries. If reliable global data on groundwater reservoirs were available, possible groundwater limitations could be represented better. Furthermore, agricultural management intensity (and the processes associated with it, such as fertilizer input, mechanization, pest and disease control, and soil conservation) is calibrated (Fader et al., 2010). This is a crude representation in need of improvement, but is in our opinion adequate for the present application, especially since we did not make projections for the future.

Obviously, it is an advancement to compute BVWC and GVWC at spatial units smaller than countries (here, $0.5^{\circ}$ resolution) and at daily resolution using climate data for the 
a. Land saved (LS)

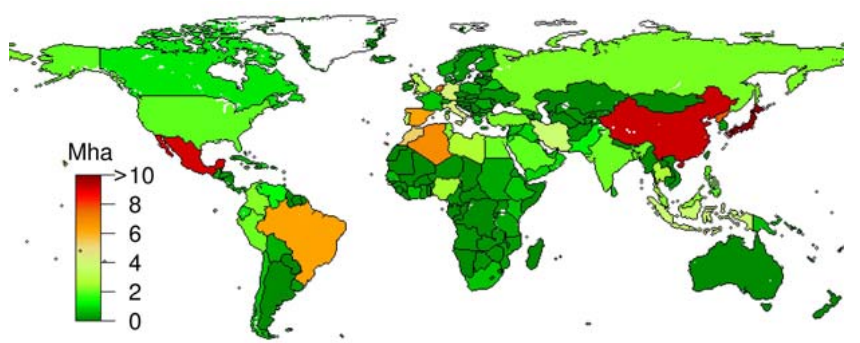

c. Net land savings (NLS)

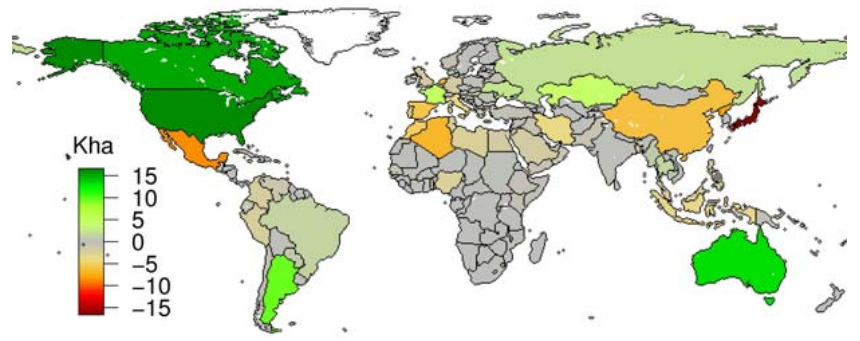

b. LS to current cropland

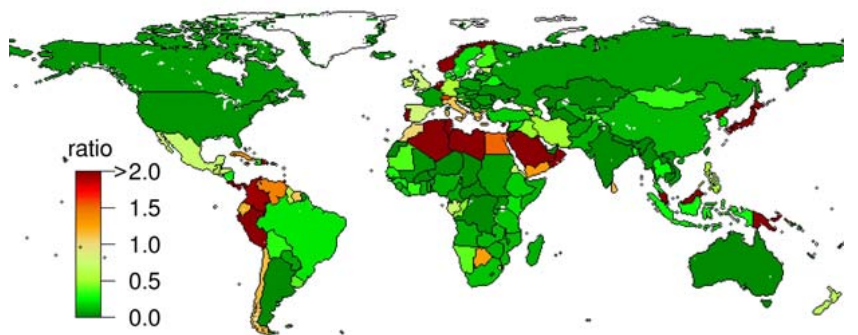

d. NLS to current cropland

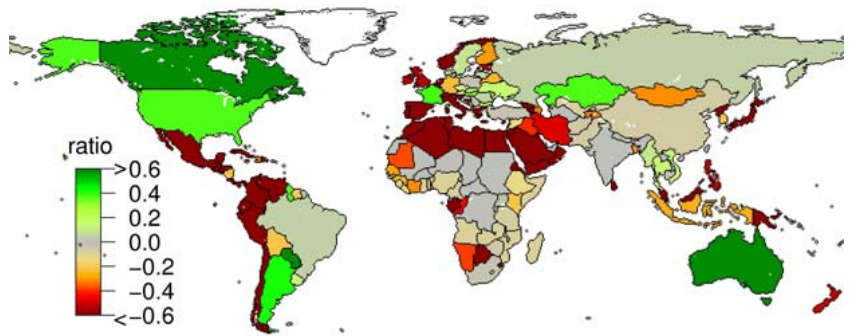

Fig. 7. (a) Land (LS, Mha) that would be required in a country's own territory for the production of imports (i.e. land saved through imports), (b) LS relative to the current sowing area of the 11 CFTs in this study (values $>1$ indicate that own production of imports would need to use more than double the present cropland extent), (c) net land savings NLS, i.e. LR-LS, and (d) NLS relative to the current sowing area of the 11 CFTs in this study. (Negative values in (c) and (d) indicate the need for cropland expansion in case of no international trade).

particular grid cells (but see Liu et al., 2009; Liu and Yang, 2010; Mekonnen and Hoekstra, 2010a,b, 2011). Nevertheless, we note that exported goods are often produced in specific areas of a country only. Hence, averaging values of BVWC and GVWC over all CFT-specific production areas of a country - as done in this study - may produce somewhat biased estimates, especially in large countries with strong climatic gradients. Future studies should thus try to identify those areas within a country where the export goods are being produced, and should also account for sub-national virtual water flows.

\subsection{Water footprints dominated by green water and country-internal consumption}

Our analysis shows that green water consumption dominates production of agricultural goods both for own consumption and for export and that IWFP are mostly higher than EWFPs. Nevertheless, a even little amounts of water consumption can be damaging or have alternative valuable uses, depending on the type of water (blue vs. green) and the local water scarcity situation. This is why future studies would have to relate the current consumption to the resource base, i.e. assess whether virtual water export aggravates water scarcity in the exporting country - see Pfister and Hellweg (2009) for an approach to weight footprints with water scarcity, and van Oel et al. (2009) for the relation between the Dutch EWFP and water scarcity in the trade partners.
Also, both green and blue water pools have different sources and opportunity costs - the costs of using water for other activities. Simply summing up both amounts makes the interpretation of WFPs difficult, if not useless. For example, Pakistan, Spain and India were shown to be blue water exporters, while many parts of these countries are usually classified by other studies as water-scarce regions (e.g. Vörösmarty et al., 2000; Gerten et al., 2011). Taking also into account that irrigation usually leads to environmental degradation (salinization, water logging, overexploitation of groundwater and surface water, etc., see e.g. Shiklomanov, 1997; Gleick, 2000) and considering that blue water has higher opportunity costs than green water, these countries are possibly making a suboptimal business in the long term by selling products produced with blue water at prices that mostly do not include externalities. On the other side, e.g. Indonesia and Brazil with their large BEWFP possibly contribute to environmental degradation in other countries by buying products produced under irrigated conditions. This is especially controversial when taking into account that both countries are not affected by water scarcity. Yet, many import countries have real constraints of resources to produce by themselves what they consume (e.g. land in Japan or water in the Middle East/North Africa region), and many economies of the export countries may collapse if they could not export any longer. For these reasons - even if isolated quantifications of the virtual water/land flows are useful for awarenessraising of the consumers - future studies should go a step 
further and link resources degradation caused by the export sector to different diets, including meat consumption.

This study is focused on agricultural goods for food, excluding industrial, livestock and household water consumption as well as some agricultural commodities such as cotton, tea and coffee. Due to the fact that only trade of raw agricultural commodities was included, some WFPs are probably over- or underestimated in net exporters or importers of processed crop products, respectively. The exclusion of industrial products should also affect only slightly our WFP estimates, since only $20 \%$ of virtual water flows correspond to non-agricultural products (Chapagain and Hoekstra, 2004). Considering the livestock sector, even if we excluded trade of cereal and seeds that were indicated to be for feed, this differentiation was not provided by COMTRADE for each country and for each commodity. Thus, especially countries with high meat consumption and importers of animal products certainly have overall WFPs higher than those presented here, and countries producing feed for animal products for export actually have lower WFPs than those presented here. For instance, the US and Australia export more than $25 \mathrm{~km}^{3}$ of virtual water in livestock products, and Italy imports a similar amount; globally, the trade of rough and processed livestock products amounts to $\sim 275 \mathrm{~km}^{3}$ (Chapagain et al., 2004; Chapagain and Hoekstra, 2008; see also Hanasaki et al., 2010, for virtual exports of pork, beef and chicken).

\subsection{Green water imports imply virtual land imports}

This is to our knowledge the first study comparing the patterns of virtual land flows to virtual water flows, which is a step forward in the understanding of the joint human appropriation of water, land and biomass (see Haberl et al., 2007 , on appropriation of photosynthesis products). Also, green water exports may be considered harmless from a water consumption point of view, since if a country would not export agricultural products and the export regions would be converted into natural vegetation, this vegetation would still consume the same or an even higher amount of green water than the agricultural plants. At the same time a country with a high GEWFP could use this argument not to think about its contribution to water scarcity in the exporting countries. These arguments were weakened in this study by demonstrating that green water exports are intrinsically linked to virtual land exports - and this land could have been used differently, e.g. for providing ecosystem services, as socially important recreation areas or as basis for other economic sectors, such as timber exploitation.

The virtual land flows presented in this study can be regarded as a component of the Ecological Footprint (EFP, the area that is needed to produce the resources consumed by a nation and absorb the waste it generates; e.g. Ewing et al., 2010). The EFP includes also the non-agricultural uses of land but omits accounting for water consumption. Moreover, EFPs give no quantitative information about the countries that are providing virtual land to others nor about the land saved by the net importers, as presented here. Thus, joining the information presented here with the EFP concept would give a more complete picture of the current human appropriation of natural resources (see Hoekstra, 2009, for a methodological comparison of EFP and WFP).

\subsection{Net savings of water and land through international agricultural trade}

This study found that current trade saves significant amounts of green and blue water and land. Net exporters, such as Argentina and Australia, use a certain amount of domestic resources for the production of export goods, i.e. they "lose" resources through trade. On the contrary, net importers like Japan and Mexico "save" domestic water and land by importing goods that need water and land to be produced.

From the perspective of resources utilization, one could minimize land and water needed globally by reallocating production to countries with high land and water efficiencies. However, this would pose several challenges: (a) Importers would increase their dependency on other countries; (b) Many countries do not have the financial means to import the goods they would need and are already today involuntarily out of the virtual land and water market (Yang and Zehnder, 2007); (c) Increasing imports, especially in countries with poorly developed rural infrastructure, could favour urban consumers, while putting pressure on the domestic agricultural sector, causing rural poverty and rural-urban migration (Yang et al., 2006); (d) Increasing exports could lead to increasing deforestation and land and water contamination (Hoekstra, 2010), but this would certainly also be caused by increased domestic production in the hypothetical case of autarky; e) High water and land productivities are frequently linked to high input use (fertilizers, pesticides), potentially leading to high pollution rates if not properly regulated (Yang and Zehnder, 2007). These aspects highlight the need for regional studies in a global context, aiming for a deeper understanding of the possible ecological and social consequences of virtual water and land trade.

Furthermore, global water savings are based on the spatial differences in VWCs: if all countries would have the same VWCs, there would be no global water saving. This could lead to confusing concepts, e.g. in that a worsening in the VWCs of net importers would indicate higher global savings (and vice versa), although the absolute amount of water consumed in such a situation would be higher. This methodology also implies that the extra production needed domestically is achieved with current crop yields and water productivities. However, this may not be true in reality, since countries may promote either intensification of the domestic agricultural sector (leading to higher land and water productivities) or use of marginal areas (leading to lower land and water productivities). 
Finally, climate change will modify the natural basis for food production (e.g. by extreme events, changes in precipitation and temperature, Solomon et al., 2007) and climate mitigation will probably restructure the energy sector, promoting the cultivation of biofuel crops (e.g. Lapola et al., 2009). This will lead to stronger land and water tradeoffs of food production and cause price increases, forcing the evaluation of virtual water/land trade as an adaptation option. Nevertheless, trade will probably keep being mainly determined by non-water related economic and political forces, such as relative prices and trade barriers (Yang et al., 2006).

\section{Appendix A}

\section{Comparison with other estimates}

This appendix offers a detailed comparison of our results with previous estimates.

\section{Blue and green virtual water contents}

We compared values of BVWC and GVWC with the very few available studies that distinguished these two components. Dabrowski et al. (2008) calculated for maize in southern Africa slightly lower values of BVWC and GVWC than we did. However, they neglected water limitations, climatic differences within the countries and differences in irrigation efficiencies, which could have led to an underestimation of VWC.

Aldaya et al.'s (2008) model-based values for maize, soybeans and wheat for the four main exporting countries agree well with our estimates for GVWC but are generally higher for BVWC.

Hanasaki et al.'s (2010) results for the main exporters of rice, soybeans, wheat and maize are very similar to our estimates, except for BVWC of rice, where Hanasaki et al. (2010) have lower values.

Comparisons for a large number of countries and for wheat with the grid cell-based study by Mekonnen and Hoekstra (2010a) also yield a good agreement (average of differences at country level for $\mathrm{BVWC}<0.2 \mathrm{~m}^{3} \mathrm{~kg}^{-1}$ and for GVWC $<0.6 \mathrm{~m}^{3} \mathrm{~kg}^{-1}$ ).

In most cases Siebert and Döll (2010) calculated similar VWC for a larger number of crops with the GCWM model, except for BVWC of pulses (lower in this study) and sugar beets (higher in this study). Possible sources of differences to that study - which was based on similar land use datasets (based on Portmann et al., 2010) - are the method for the calculation of evapotranspiration (this study, Priestley-Taylor method; Siebert and Döll, 2010, Penman-Monteith method; see their study for discussion of this aspect), and the different treatment of growing periods (LPJmL, dynamic sowing and harvesting dates; GCWM, fixed growing periods from crop calendars).
During final preparation of this manuscript a report of Mekonnen and Hoekstra (2010b) was published with a lot of similarities to this study. A corresponding journal paper (Mekonnen and Hoekstra, 2011) is currently under discussion and review in HESS. We compared the results shown in the Tables 3 and 4 of the report with our BVWC and GVWC and noted a good agreement, except for groundnuts (their estimate is much lower for BVWC) and cassava (their estimate is much lower for GVWC). Reasons for discrepancies could be the different time period (theirs 1996-2005) and differences in the preparation of the land use inputs.

\section{Virtual water flows and water footprints}

As can be seen in Table A1, LPJmL-computed total VWE values compare well with those found by Chapagain and Hoekstra (2004, Appendix XIX). Oki and Kanae (2004) compute much higher values for temperate cereals and rice; one likely reason is that they assumed a constant global average crop water requirement and no differences between the growth stages. Our values for wheat compare well with the grid-based values found by Mekonnen and Hoekstra (2010a), while there are unsystematic differences between our values and those found by Hanasaki et al. (2010) - likely due to differences in the trade data used, since the agreement in VWC is quite good (see above).

The global BWFP $\left(449 \mathrm{~km}^{3}\right)$ calculated in the present study is lower than the blue water consumption computed by Liu et al. (2009) with the GEPIC model $\left(720 \mathrm{~km}^{3}\right)$ as they considered more crops (17 in total). Adding the water footprint of the collectively parameterized "other crops" so as to approximate the footprint of all crops, we obtain a blue water consumption of $923 \mathrm{~km}^{3}$, which is almost equal to the value of GEPIC $\left(927 \mathrm{~km}^{3}\right)$ reported in Hoff et al. (2010). This value is also comparable to the LPJmL-based study by Rost et al. $2008\left(1258 \mathrm{~km}^{3}\right.$; the remaining difference is because that study was based on a different land use dataset with some differences in parameterizations, and no calibration of management was performed). A CFT-specific comparison with the values of Siebert and Döll (2010) also yields a very good agreement, even if LPJmL calculates lower values for temperate cereals and rice (Table A1).

GWFP represent in our calculations $84 \%$ of total crop water consumption. This percentage value is very similar to the $81 \%$ found by Liu et al. (2009) and exactly the same as found by Liu and Yang (2010), in both cases for a similar sets of crops and the same time frame, but the absolute value is lower than found in earlier studies (Rost et al., 2008: $7242 \mathrm{~km}^{3}$; Liu et al., 2009: $3103 \mathrm{~km}^{3}$; Siebert and Döll, 2010: $5731 \mathrm{~km}^{3}$; Hoff et al., 2010: 4975-5731 km³ ). However, an estimate for all crops including the "other crops" yields about $6000 \mathrm{~km}^{3}$, which is of the same order than the above estimates. 
Table A1. Comparison of VWE, WFP, WS and NWS with other estimates. All values in $\mathrm{km}^{3}$.

\begin{tabular}{|c|c|c|c|c|c|c|c|c|c|c|c|c|c|c|c|c|c|c|c|}
\hline \multirow[t]{2}{*}{ CFT } & \multicolumn{3}{|c|}{ BVWE } & \multicolumn{3}{|c|}{ GVWE } & \multicolumn{3}{|c|}{ VWE } & \multicolumn{2}{|c|}{ BWFP } & \multicolumn{2}{|c|}{ GWFP } & \multicolumn{3}{|c|}{ WS } & \multicolumn{3}{|c|}{ NWS } \\
\hline & $\begin{array}{r}\text { This } \\
\text { study }\end{array}$ & $\begin{array}{r}\text { Hanasaki } \\
\text { et al. } \\
(2010)^{1}\end{array}$ & $\begin{array}{r}\text { Mekonnen } \\
\text { and } \\
\text { Hoekstra } \\
(2010)^{2}\end{array}$ & $\begin{array}{r}\text { This } \\
\text { study }\end{array}$ & $\begin{array}{r}\text { Hanasaki } \\
\text { et al. } \\
(2010)^{1}\end{array}$ & $\begin{array}{r}\text { Mekonnen } \\
\text { and } \\
\text { Hoekstra } \\
(2010)^{2}\end{array}$ & $\begin{array}{r}\text { This } \\
\text { study }\end{array}$ & $\begin{array}{r}\text { Oki and } \\
\text { Kanae } \\
(2004)^{3}\end{array}$ & $\begin{array}{r}\text { Chapagain } \\
\text { et al. } \\
(2004)^{4}\end{array}$ & $\begin{array}{l}\text { This } \\
\text { study }\end{array}$ & $\begin{array}{r}\text { Siebert } \\
\text { et al. } \\
(2010)\end{array}$ & $\begin{array}{l}\text { This } \\
\text { study }\end{array}$ & $\begin{array}{r}\text { Siebert } \\
\text { et al. } \\
(2010)\end{array}$ & $\begin{array}{l}\text { This } \\
\text { study }\end{array}$ & $\begin{array}{r}\text { Yang } \\
\text { et al. } \\
(2006)^{5}\end{array}$ & $\begin{array}{r}\text { Oki and } \\
\text { Kanae } \\
(2004)^{3}\end{array}$ & $\begin{array}{l}\text { This } \\
\text { study }\end{array}$ & $\begin{array}{r}\text { Yang } \\
\text { et al. } \\
(2006)^{5}\end{array}$ & $\begin{array}{r}\text { Oki and } \\
\text { Kanae } \\
(2004)^{3}\end{array}$ \\
\hline \multicolumn{20}{|l|}{ Temperate } \\
\hline Cereals & 4.61 & 16.40 & 7.78 & 151.90 & 127.30 & 174.69 & 156.51 & 270.90 & 129.05 & 126.91 & 220.30 & 572.77 & 834.75 & 229.01 & 373.9 & 464.20 & -72.50 & -150.40 & -193.30 \\
\hline Rice & 12.34 & 15.20 & & 22.12 & 19.80 & & 34.46 & 110.70 & 74.02 & 197.48 & 307.33 & 480.82 & 634.09 & 51.96 & 53.50 & 185.60 & -17.50 & 10.10 & -74.90 \\
\hline Maize & 5.10 & 8.10 & & 71.80 & 47.80 & & 76.90 & 51.70 & 39.20 & 66.38 & 72.65 & 526.29 & 585.40 & 190.85 & 97.30 & 127.00 & -113.96 & -57.40 & -75.30 \\
\hline Tropical Cereals & 0.79 & & & 16.25 & & & 17.05 & & 7.30 & 13.79 & 14.98 & 165.83 & 302.61 & 18.35 & & & -1.30 & & \\
\hline Pulses & 0.48 & & & 15.27 & & & 15.75 & & 7.83 & 12.71 & 22.99 & 129.91 & 173.22 & 17.24 & & & -1.49 & & \\
\hline Temperate Roots & 0.05 & & & 0.15 & & & 0.19 & & 0.20 & 5.09 & 9.14 & 21.80 & 19.82 & 0.19 & & & 0.01 & & \\
\hline Tropical Roots & 0.00 & & & 6.54 & & & 6.54 & & 1.98 & 0.02 & 0.06 & 102.95 & 143.56 & 14.41 & & & -7.87 & & \\
\hline Sunflower & 0.12 & & & 7.27 & & & 7.39 & & 11.24 & 2.26 & 4.19 & 43.05 & 67.60 & 9.17 & & & -1.78 & & \\
\hline Soybeans & 1.05 & 3.20 & & 64.06 & 88.10 & & 65.11 & 84.00 & 79.46 & 5.66 & 17.31 & 179.06 & 382.13 & 100.69 & 104.90 & 118.10 & -35.58 & -37.10 & -34.10 \\
\hline Groundnuts & 0.07 & & & 0.47 & & & 0.55 & & 3.69 & 8.04 & 7.61 & 67.78 & 90.07 & 0.88 & & & -0.33 & & \\
\hline Rapeseed & 0.01 & & & 12.88 & & & 12.89 & & 16.15 & 10.21 & 7.99 & 51.86 & 51.06 & 24.00 & & & -11.11 & & \\
\hline
\end{tabular}

${ }^{1}$ From their Table 8 , for temperate cereals, sum of barley and wheat.

2 From their Appendix IX.

3 From their Table 3 , for temperate cereals only wheat.

${ }^{4}$ From their Appendix XIX, only rough product categories used; for temperate cereals: sum of oats, rye, barley and wheat; for tropical cereals: sorghum and millet, for pulses: peas, chickpeas and lentils.

5 From their Table 2; for temperate cereals, sum of wheat and barley; signs were inverted for NWS to make the numbers comparable with the present study.

Table A2. Comparison of virtual land flows with other estimates. All values in Mha.

\begin{tabular}{l|rrr|rr}
\hline CFT & \multicolumn{3}{|c|}{ VLI } & \multicolumn{2}{c}{ VLE } \\
\hline & $\begin{array}{r}\text { This } \\
\text { study }\end{array}$ & $\begin{array}{r}\text { van } \\
\text { Sleen } \\
(2005)^{1}\end{array}$ & $\begin{array}{r}\text { Witzke and } \\
\text { Noleppa } \\
(2010)^{2}\end{array}$ & $\begin{array}{r}\text { This } \\
\text { study }\end{array}$ & $\begin{array}{r}\text { Witzke and } \\
\text { Noleppa } \\
2010^{2}\end{array}$ \\
\hline Temperate Cereals & 9.406 & 2.95 & 2.57 & 9.304 & 3.28 \\
Rice & 0.586 & 0 & 0.53 & 0.235 & 0.04 \\
Maize & 2.539 & 0.47 & 2.48 & 2.284 & 0.56 \\
Tropical Cereals & 0.401 & 0.1 & & 0.095 & \\
Pulses & 1.470 & 1.57 & & 0.494 & \\
Temperate Roots & 0.015 & 0 & & 0.017 & \\
Tropical Roots & 0.894 & 0 & & 0.000 & \\
Sunflower & 2.389 & 1.04 & & 0.932 & \\
Soybeans & 8.650 & 4.92 & 19.24 & 0.061 & 1.71 \\
Groundnuts & 0.049 & 0.04 & & 0.000 & \\
Rapeseed & 1.466 & 0.02 & & 1.541 & \\
\hline
\end{tabular}

${ }^{1}$ From Table 9, only data on VLI, for the year 2005. For temperate cereals sum of wheat and barley, for tropical cereals sum of millet and sorghum, for pulses sum of chicken peas, dry peas and dry beans.

2 From their Fig. 7, for the years 2007/2008.

The CFT-specific comparison of GWFP with the global values of Siebert and Döll (2010) yields a very good agreement, though LPJmL calculates lower values for temperate and tropical cereals, rice and soybeans (Table A1). Compared with Hoekstra and Chapagain (2007) - who, however, did neither consider climate variability within countries nor water stress - the agreement of CFT-specific WFP values is pretty good, except for rice and temperate cereals where their estimates are higher (data not shown).

\section{Water savings}

Comparison of WS with other estimates reveals a good agreement for maize and soybeans with Yang et al. (2006) and unsystematic differences with Oki and Kanae (2004) (Table A1). Concerning NWS, the respective values of Yang et al. (2006) for soybeans are in good agreement but we obtained higher net water savings for maize and lower ones for temperate cereals (see Table A1). While those authors calculated a positive NWS for rice, the present study calculated a negative one. Moreover, our global NWS is slightly lower than theirs $\left(263 \mathrm{~km}^{3}\right.$ vs. $\left.337 \mathrm{~km}^{3}\right)$. Differences can again be caused by different methods used to compute evapotranspiration (Penman-Monteith vs. Priestley-Taylor) and because Yang et al. (2006) used VWC computed by the model CROPWAT, which does not consider water stress even in rainfed agriculture and which was run at country level, using only the climate of the capital city. 

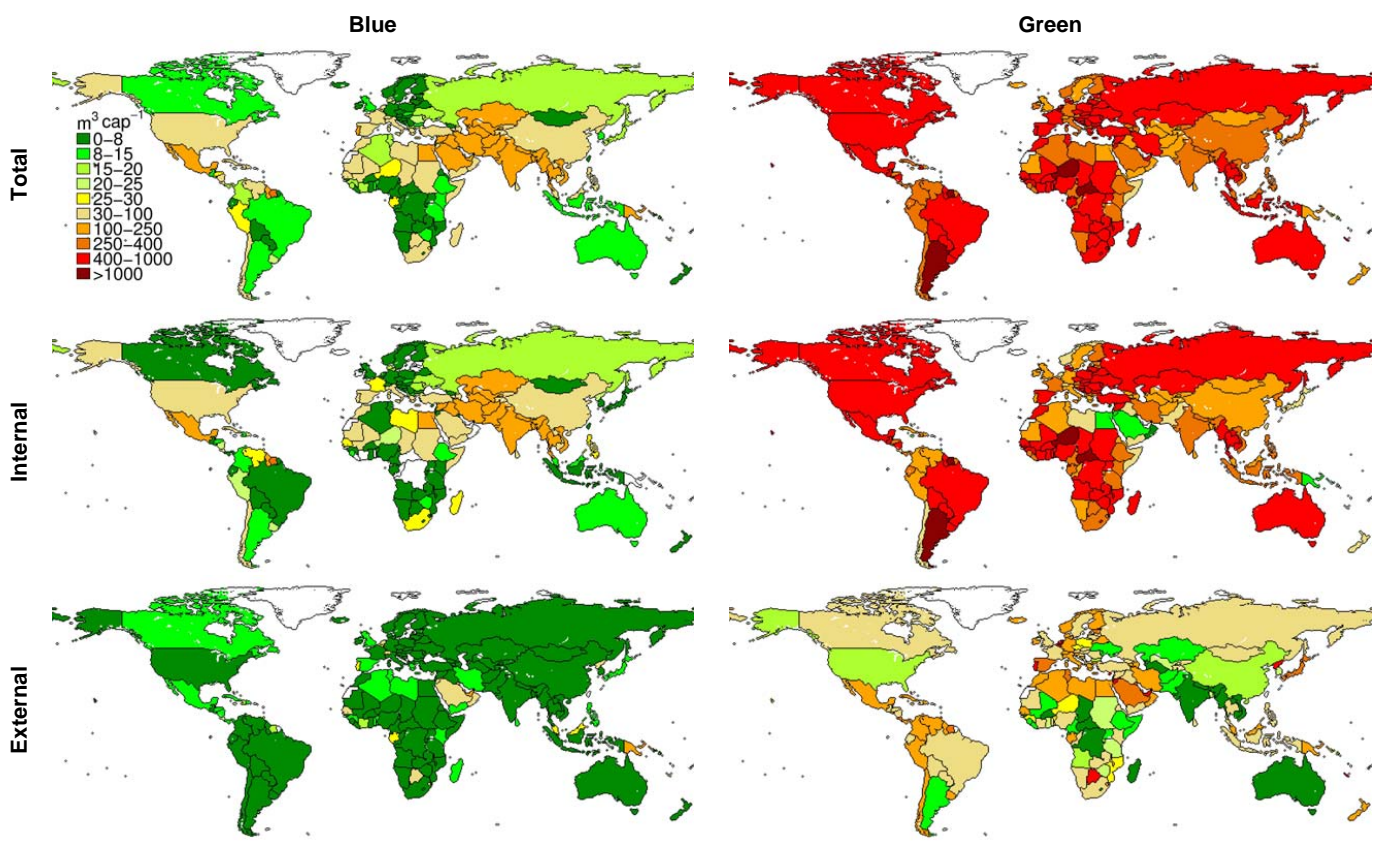

Fig. B1. External, internal and total blue and green water footprints per capita for all 11 CFTs, 1998-2002 average.

De Fraiture et al. (2004) computed water savings for cereals similar to ours with the IMPACT model $\left(276 \mathrm{~km}^{3}\right.$; LPJmL, $206 \mathrm{~km}^{3}$ ), though they used a different time period (1995), different trade data and, as a whole, different modelling approaches.

Comparing NWS with Oki and Kanae (2004), the sign agrees for all crops considered and there is a very good agreement in the absolute values for soybeans, but unsystematic differences for other CFTs (Table A1).

Chapagain et al. (2006) unfortunately do not provide CFT differentiated water savings, we thus could not compare our CFT estimates with that study. Their global estimate for what we called WS related to trade in crop products (i.e. the water needed to produce imports domestically) is $1286 \mathrm{~km}^{3}$ (in our study $657 \mathrm{~km}^{3}$ ), and for what we called NWS they computed $307 \mathrm{~km}^{3}$ (our study $263 \mathrm{~km}^{3}$ ). These numbers are however not directly comparable due to the differences in the list of commodities considered.

\section{Virtual land flows}

To our best knowledge, there are no studies on the global scale quantifying virtual land flows of agricultural goods, except for some estimates for certain regions and commodities; namely Steger (2005), van der Sleen (2005) and von Witzke and Noleppa (2010) computed virtual land flows from and to the European Union. Steger (2005), however, provided no crop-specific information, thus the comparison shown in Table A2 contains only the remaining two studies. As can be seen, there are unsystematic discrepancies between all estimates, two possible sources are the different trade data used (this study, COMTRADE; van Sleen, 2005, WATM; von Witzke and Noleppa, 2010, EUROSTAT) and the various period of time considered.

We compared the net importing and exporting countries (Map 7 in Ewing et al., 2010) with our VLB and found clear similarities in the spatial patterns, with some exceptions: France and India are net importers in Ewing et al. (2010), while we calculate a net export from those countries, and the Philippines, Mexico and some Andean countries are net exporters in Ewing et al. (2010), while we calculate a net import. The differences could be due to the fact that we only consider agricultural goods, while EFPs are calculated considering also industrial products and waste assimilation.

\section{Appendix B}

\section{External, internal and total WFP per capita}

See Sects. 4.3.1 and 4.3.2 for explanation of the Fig. B1 provided here. 
Acronyms (alphabetically)

BE, GE, E

BEWFP, GEWFP, EWFP

BIWFP, GIWFP, IWFP

BVWB, GVWB, VWB

BVWC, GVWC, VWC

BVWE, GVWE, VWE

BVWI, GVWI, VWI

BWFP, GWFP

CFT

$E_{\mathrm{I}}, E_{\mathrm{T}}, E_{\mathrm{S}}$

Ex

Im

LR

LS

NLS

NWS

Pop

VLB

VLE

VLI

VWF

WFP

WR

WS

$Y_{\mathrm{Irr}}, Y_{\mathrm{Ra}}, Y$
Blue, Green and Total Evapotranspiration (interception, evaporation and transpiration)

Blue, Green and Total

External Water Footprint

Blue, Green and Total

Internal Water Footprint

Blue, Green and Total

Virtual Water Balance

Blue, Green and Total

Virtual Water Content

Blue, Green and Total

Virtual Water Export

Blue, Green and Total

Virtual Water Import

Blue and Green Water

Footprint (internal and ex-

ternal)

Crop Functional Type

Interception, Transpira-

tion, Evaporation

Exports

Imports

Land Released

Land Saving

Net Land Saving

Net Water Saving

Population

Virtual Land Balance

Virtual Land Exported

Virtual Land Imported

Virtual Water Flow

Water footprint (external

and internal, blue and

green)

Water Released

Water Saving

Irrigated Yield, Rainfed

Yield, Total Yield

Acknowledgements. This study was funded by the German Ministry for Education and Research (BMBF) through the projects "The Price of Water - Valuation of global water resources with a dynamic optimization approach", "NAWAMA - Sustainable water management in a globalized world" and "GLUES - Global Assessment of Land Use Dynamics on Greenhouse Gas Emissions and Ecosystem Services", as well as by the EU-funded Integrated Project WATCH (contract no. 036946). We thank Ursula Heyder, Sibyll Schaphoff, Alberte Bondeau, Christoph Schmitz and Holger Hoff for valuable discussions, comments, and technical support. We also thank the World Climate Research Programme's (WCRP's) Coupled Model Intercomparison Project phase 3 (CMIP3) multimodel for the provision of the climate projections, the Commodity

Trade Statistics Database for the trade data, IIASA for the provision of population data and Felix Portmann for the provision of the MIRCA2000 dataset. Special thanks to one anonymous reviewer and to Stefan Siebert, Balázs Fekete and Arjen Hoekstra for the interactive online discussion.

The service charges for this open access publication have been covered by the Max Planck Society.

Edited by: J. Liu

\section{References}

Aldaya, M. M., Hoekstra, A. Y., and Allan, J. A.: Strategic importance of green water in international crop trade, Value of Water Research Report Series No. 25, 30 pp., 2008.

Aldaya, M. M., Allan, J. A., and Hoekstra, A. Y.: Strategic importance of green water in international crop trade, Ecol. Econ., 69, 887-894, 2010.

Biemans, H., Hutjes, R., Kabat, P., Strengers, B., Gerten, D., and Rost, S.: Impacts of precipitation uncertainty on discharge calculations for main river basins, J. Hydrometeorol., 10, 1011-1025, 2009.

Bondeau, A., Smith, P., Zaehle, S., Schaphoff, S., Lucht, W. Cramer, W., Gerten, D., Lotze-Campen, H., Müller, C., Reichstein, M., and Smith, B.: Modelling the role of agriculture for the 20th century global terrestrial carbon balance, Global Change Biol., 13, 679-706, 2007.

Chapagain, A. K., Hoekstra, A. Y., Savenije, H. H. G., and Gautam, R.: The water footprint of cotton consumption, Value of Water Research Report Series No. 18, Delft: UNESCO-IHE, 2005.

Chapagain, A. K., Hoekstra, A. Y., and Savenije, H. H. G.: Water saving through international trade of agricultural products, Hydrol. Earth Syst. Sci., 10, 455-468, doi:10.5194/hess-10-4552006, 2006.

Chapagain, A. K. and Hoekstra, A. Y.: Water footprints of nations, Research Report Series No. 16, 75 pp., 2004.

Chapagain, A. K. and Hoekstra, A. Y.: The global component of freshwater demand and supply: an assessment of virtual water flows between nations as a result of trade in agricultural and industrial products, Water Internat., 33, 19-32, 2008.

Dabrowski, J. M., Masekoameng, E., and Ashton, P. J.: Analysis of virtual water flows associated with the trade of maize in the SADC region: importance of scale, Hydrol. Earth Syst. Sci., 13, 1967-1977, doi:10.5194/hess-13-1967-2009, 2009.

de Fraiture, C., Cai, X., Amarasinghe, U., Rosegrant, M., and Molden, D.: Does international cereal trade save water? The impact of virtual water trade on global water use. Comprehensive assessment of water management in agriculture, Value of Water Research Report Series No. 4, Delft: UNESCO-IHE, 2004.

Ewing, B., Moore, D., Goldfinger, S., Oursler, A., Reed, A., and Wackernagel, M.: The Ecological Footprint Atlas 2010, Oakland: Global Footprints Network, 2010.

Fader, M., Rost, S., Müller, C., Bondeau, A., and Gerten, D.: Virtual water content of temperate cereals and maize: present and potential future patterns, J. Hydrol., 384, 218-231, 2010.

IIASA (International Institute for Applied Systems Analysis), FAO (Food and Agriculture Organization of the United Nations): 
Joined Global Agro-Ecological Zones Project (Global-AEZ) version 1.0, CD-ROM, 2000.

Gerten, D., Schaphoff, S., Haberlandt, U., Lucht, W., and Sitch, S.: Terrestrial vegetation and water balance. Hydrological evaluation of a dynamic global vegetation model, J. Hydrol., 286, 249-270, 2004.

Gerten, D., Schaphoff, S., and Lucht, W.: Potential future changes in water limitations of the terrestrial biosphere, Clim. Change, 80, 277-299, 2007.

Gerten, D., Heinke, J., Hoff, H., Biemans, H., Fader, M., and Waha, K.: Global water availability and requirements for future food production, J. Hydrometeorol., in press, 2011.

Gleick, P. H.: The world's water 2000-2001, The Biennial report on freshwater resources, Inland Press, 315 pp., 2000.

Grübler, A., O’Neill, B., Riahi, K., Chirkov, V.,Goujon, A., Kolp, P., Prommer, I., Scherbov, S., and Slentoe, E.: Regional, national, and spatially explicit scenarios of demographic and economic change based on SRES, Technol. Fore. Soc. Change, 74, 9801029, 2007.

Haberl, H., Erb, K.-H., Krausmann, F., Gaube, V., Bondeau, A., Plutzar, C., Gingrich, S., Lucht, W., and Fischer-Kowalski, M.: Quantifying and mapping the human appropriation of net primary production in earth's terrestrial ecosystems, Proc. Nat. Acad. Sci. USA, 104, 12942-12947, 2007.

Hanasaki, N., Inuzuka, T., Kanae, S., and Oki, T.: An estimation of global virtual water flow and sources of water withdrawal for major crops and livestock products using a global hydrological model, J. Hydrol., 384, 232-244, 2010.

Hoekstra, A. Y.: Human appropriation of natural capital: A comparison of ecological footprint and water footprint analysis, Ecol. Econ., 68, 1963-1974, 2009.

Hoekstra, A. Y.: The relation between international trade and freshwater scarcity, WTO Working Paper, http://www.wto.org/ english/res_e/reser_e/ersd201005_e.pdf, 2010.

Hoekstra, A. Y. and Chapagain, A. K.: Water footprints of nations: water use by people as a function of their consumption pattern, Water Resour. Manag., 21, 35-48, 2007.

Hoekstra, A. Y. and Hung, P. Q.: Virtual water trade. A quantification of virtual water flows between nations in relation to international crop trade, Value of Water Research Report Series No. 11, Delft: UNESCO-IHE, 2002.

Hoff, H., Falkenmark, M., Gerten, D., Gordon, L., Karlberg, L., and Rockström, J.: Greening the global water system, J. Hydrol., 384, 177-186, 2010.

Jackson, R. B., Canadell, J., Ehleringer, J. R., Mooney, H. A., Sala, O. E., and Schulze, E. D.: A global analysis of root distributions for terrestrial biomesm, Oecologia, 108, 389-411, 1996.

Lapola, D., Priess, J. A., and Bondeau, A.: Modeling the land requirements and potential productivity of sugarcane and jastropha in Brazil and India using the LPJmL dynamic global vegetation model, Biomass Bioen., 33, 1087-1095, 2009.

Liu, J. and Savenije, H. H. G.: Food consumption patterns and their effect on water requirement in China, Hydrol. Earth Syst. Sci., 12, 887-898, doi:10.5194/hess-12-887-2008, 2008.

Liu, J. and Yang, H.: Spatially explicit assessment of global consumptive water uses in cropland: Green and blue water, J. Hydrol., 384, 187-197, 2010.

Liu, J., Yang, H., and Savenije, H. H. G.: Chinas move to higher meat-diet hits water security, Nature, 454, 397, 2008.
Liu, J., Zehnder, A. J. B., and Yang, H.: Global consumptive water use for crop production: the importance of green water and virtual water, Water Resour. Res., 45, W05428, doi:10.1029/2007WR006051, 2009.

Mekonnen, M. M. and Hoekstra, A. Y.: A global and highresolution assessment of the green, blue and grey water footprint of wheat, Value of Water Research Report Series No. 42, Delft: UNESCO-IHE, 2010a.

Mekonnen, M. M. and Hoekstra, A. Y.: The green, blue and grey water footprint of crops and derived crop products, Value of Water Research Report Series No. 47, Delft: UNESCO-IHE, 2010 b.

Mekonnen, M. M. and Hoekstra, A. Y.: The green, blue and grey water footprint of crops and derived crop products, Hydrol. Earth Syst. Sci. Discuss., 8, 763-809, doi:10.5194/hessd-8-763-2011, 2011.

Molden, D., Oweis, T. Y., Pasquale, S., Kijne, J. W., Hanjra, M. A., Bindraban, P. S., Bouman, B. A. M., Cook, S., Erenstein, O., Farahani, H., Hachum, A., Hoogeveen, J., Mahoo, H., Nangia, V., Peden, D., Sikka, A., Silva, P., Turral, H., Upadhyaya, A., and Zwart, S.: Pathways for increasing agricultural water productivity, in: Water for Food, Water for Life, A Comprehensive Assessment of Water Management in Agriculture, 279-310, London and Colombo: Earthscan and International Water Management Institute, 2007.

Oki, T. and Kanae, S.: Virtual water trade and world water resources, Water Sci. Technol., 203-209, 2004.

Portmann, F., Siebert, S., and Döll, P.: MIRCA2000 - Global monthly irrigated and rainfed crop areas around the year 2000: A new high-resolution data set for agricultural and hydrological modeling, Global Biogeochem. Cy., 24, GB1011, doi:10.1029/2008GB003435, 2010.

Pfister, S. and Hellweg, S.: The water "shoesize" vs. footprint of bioenergy, Proc. Nat. Acad. Sci. USA, 106, E93-E94, 2009.

Pfister, S., Koehler, A., and Hellweg, S.: Assessing the environmental impacts of freshwater consumption in LCA, Environ. Sci. Technol., 43, 4098-4104, 2009.

Rockström, J., Falkenmark, M., Karlberg, L., Hoff, H., Rost, S., and Gerten, D.: Future water availability for global food production: the potential of green water for increasing resilience to global change, Water Resour. Res., 45, W00A12, doi:10.1029/2007WR006767, 2009.

Rosegrant, M. W. and Sombilla, M. A.: Critical issues suggested by trends in food, population, and the environment to the year 2020, Am. J. Agric. Econ., 5, 1467-1470, 1997.

Rost, S., Gerten, D., Bondeau, A., Lucht, W., Rohwer, J., and Schaphoff, S.: Agricultural green and blue water consumption and its influence on the global water system, Water Resour. Res., 44, W09405, doi:10.1029/2007WR006331, 2008.

Shiklomanov, I. A. (ed.): Comprehensive Assessment of the Freshwater Resources of the World. Assessment of Water Resources and Water Availability in the World. Stockholm: Stockholm Environment Institute and World Meteorological Organization, 88 pp., 1997.

Siebert, S. and Döll, P.: Quantifying blue and green virtual water contents in global crop production as well as potential production losses without irrigation, J. Hydrol., 384, 198-217, 2010.

Sitch, S., Smith, B., Prentice, C., Arneth, A., Bondeau, A., Cramer, W., Kaplan, J.O., Levis, S., Lucht, W., Sykes, M.T., Thonike, K., and Venevsky, S.: Evaluation of ecosystem dynamics, plant ge- 
ography and terrestrial carbon cycling in the LPJ dynamic global vegetation model, Global Change Biol., 9, 161-185, 2003.

Solomon, S., Qin, D., Manning, M., Chen, Z., Marquis, M., Averyt, K. B., Tignor, M., Miller, H. L. (eds.): Contribution of Working Group I to the Fourth Assessment Report of the Intergovernmental Panel on Climate Change. Cambridge and New York: Cambridge University Press, 2007.

Steinfeld, H., Gerber, P., Wassenaar, T., Castel, V., Rosales, M., and de Haan, C.: Livestock's long shadow. Environmental issues and options, Rome: FAO, 2006.

Steger, S.: Der Flächenrucksack des europäischen Außenhandels mit Agrarprodukten, Wuppertal Institut für Klima, Umwelt, Energie GmbH, 2005.

UNEP: Vital Water Graphics. An Overview of the State of the World's Fresh and Marine Waters, 2nd edn., http://www.unep. org/dewa/vitalwater/article77.html, last access: 2 August 2010 , 2008.

van Oel, P. R., Mekonnen, M. M., and Hoekstra, A. Y.: The external water footprint of the Netherlands: Geographically-explicit quantification and impact assessment, Ecol. Econ., 69, 82-92.

van Sleen, M.: EU virtual land flows, An assessment of EU agricultural land use through international trade, Master thesis at the University of Groningen, http://ivem.eldoc.ub.rug.nl/FILES/ivempubs/dvrapp/EES-2009/ EES-2009-70M/EES-2009-70M_ManelvanderSleen.pdf, last access: 17 December 2010, 2009. von Witzke, H. and Noleppa, S.: EU agricultural production and trade: can more efficiency prevent increasing "land-grabbing" outside of Europe?, Research Report, Piacenca: University of Piacenca, 2010.

Vörösmarty, C., Green, P., Salisbury, J., and Lammer, R. B.: Global Water Resources: vulnerability from climate change and population growth, Science, 289, 284-288, 2000.

Waha, K., van Bussel, L. G. J., Müller, C., and Bondeau, A.: Climate-driven simulation of global crop sowing dates, Global Ecol. Biogeogr., in press, 2011.

Yang, H. and Zehnder, A.: "Virtual water": An unfolding concept in integrated water resources management, Water Resour. Res., 43, W12301, doi:10.1029/2007WR006048, 2007.

Yang, H., Reichert, P., Abbaspour, K. C., and Zehnder, A. J. B.: A water resources threshold and its implications for food security, Environ. Sci. Technol., 37, 3048-3054, 2003.

Yang, H., Wang, L., Abbaspour, K. C., and Zehnder, A. J. B.: Virtual water trade: an assessment of water use efficiency in the international food trade, Hydrol. Earth Syst. Sci., 10, 443-454, doi:10.5194/hess-10-443-2006, 2006. 